IRSH 60 (2015), pp. I-35 doi:10.1017/S0020859015000024 (C) 2015 Internationaal Instituut voor Sociale Geschiedenis

\title{
Revolting Peasants: Southern Italy, Ireland, and Cartoons in Comparative Perspective, I860-I882*
}

\author{
Nia L L WheLEHA N \\ School of History, Classics and Archaeology, \\ University of Edinburgh \\ William Robertson Wing, Old Medical School, \\ Teviot Place, Edinburgh, EH8 9AG, UK \\ E-mail: niall.whelehan@ed.ac.uk
}

\begin{abstract}
AвSTRACT: Peasants in general, and rural rebels in particular, were mercilessly ridiculed in the satirical cartoons that proliferated in European cities from the mid-nineteenth century. There was more to these images than the age-old hostility of the townspeople for the peasant, and this article comparatively explores how cartoons of southern Italian brigands and rural Irish agitators helped shape a liberal version of what was modern by identifying what was not: the revolting peasant who engaged in "unmanly" violence, lacked self-reliance, and was in thrall to Catholic clergymen. During periods of unrest, distinctions between brigands, rebels, and the rural populations as a whole were not always clear in cartoons. Comparison suggests that derogatory images of peasants from southern Italy and Ireland held local peculiarities, but they also drew from transnational stereotypes of rural poverty that circulated widely due to the rapidly expanding European publishing industry. While scholarly debates inspired by postcolonial perspectives have previously emphasized processes of othering between the West and East, between the metropole and colony, it is argued here that there is also an internal European context to these relationships based on ingrained class and gendered prejudices, and perceptions of what constituted the centre and the periphery.
\end{abstract}

In the I880s an English anthropologist travelling in the Mediterranean observed that the "people of Southern Italy seem born brigands [...] very different are they from their grave, thoughtful brethren of the north. They form the element of national discord, the Irish of Italy." Ireland and southern Italy, or the mezzogiorno, regularly provided reverse images of modernity for an array of commentators in the nineteenth century.

* My thanks to Michael de Nie and Enrico Dal Lago for their comments on drafts of this article, and to the IRSH editorial board and anonymous reviewers for their helpful suggestions. Translations from Italian are mine.

I. Anne W. Buckland, The World beyond the Esterelles, 2 vols (London, I884), II, pp. I63-I64. 
Stereotypes about indolence, violence, and dependency in geographically peripheral regions were widespread in British and Italian cities and contributed to how the national self-image and the other were imagined. Cartoons contributed significantly to this imaginary. From the I 840 , satirical magazines developed within the growing European media industry as a means of communication with a fresh immediacy, and peasants were often the subjects of ruthless ridicule. A key characteristic of processes of modernity, Eisenstadt argued, is "the redefinition of center and periphery", ${ }^{2}$ and satirical cartoons shaped a liberal version of what was modern by identifying what was not: the peasant who engaged in cowardly acts of violence, lacked self-reliance, avoided work, and was in thrall to Catholic clergymen. ${ }^{3}$

Humorous magazines in nineteenth-century Italy and the United Kingdom were not universally hostile to rural dwellers, who were often held up as salt-of-the-earth figures. Farmers could often be gently mocked as old-fashioned, but they were also portrayed as nobly upholding traditional virtues that were untainted by the ills of industrialization. Comic dialogues between law-abiding Irish farmers and English travellers and sportsmen were often accompanied by images with no negative connotations. In many Italian cartoons, peasants' physical characteristics were not discernibly different from urban or elite figures. It was the rebels and brigands who were the cartoonists' principal targets.

At the same time, distinctions between these politicized groups and the rural populations as a whole in Ireland and southern Italy were not always clear. During times of political upheaval, caricatures of rebellious peasants came to embody the worst aspects of the regions they inhabited, combining traits of laziness and dependency with "unmanly" violence. These images reveal important aspects of social and political attitudes toward the rural lower classes in southern Italy and Ireland; at the same time, they were constitutive of these attitudes amongst an urban middle-class readership. By visually articulating undesirable characteristics, cartoons of brigands and rebels contributed to the invention of a bourgeois image of nationhood in Italy and the United Kingdom, which asserted the superiority of liberal capitalism and the industrious, urban citizen.

Over the past decade or so the historiography of Italian unification has been transformed by research that has moved away from traditional

\footnotetext{
2. Shmuel N. Eisenstadt, "Multiple Modernities", Daedalus, I29 (2000), pp. I-29, I 5.

3. Periphery is employed here in the sense of being geographically, culturally, and economically distant from metropolitan centres that house government and administrative institutions. For a useful discussion see Marta Petrusewicz, "Ex-centric Europe: Visions and Practices of Harmonious Modernization in the igth-Century European Peripheries (Ireland, Norway, Poland and Two Sicilies)", in Luca Giuliani and Dieter Grimm (eds), Wissenschaftskolleg zu Berlin, Jabrbuch 2006/07 (Berlin, 2008), pp. 278-293.
} 
politics toward understanding the Risorgimento as a cultural revolution. The work of Alberto Banti has been to the forefront of a cultural turn, which has brought a focus on language, representations, and the imaginary of the Risorgimento. ${ }^{4}$ Transnational and comparative perspectives have had a limited influence on the historiography of nineteenth-century Italy, and Ireland, relative to their popularity in North America and central European countries. Yet, new approaches, Maurizio Isabella has pointed out, are starting to "locate Italy's nation-building at the centre of European-wide processes of change, such as the media revolution of the nineteenth century $[\ldots]$ most of the peculiarities of the Risorgimento now seem to be local variants of European or global trends". S This article seeks to contribute to these developments by comparing cartoons of Italian brigands and Irish agrarian agitators.

Distorted images of peasants came to the fore particularly during times of trauma. Following unification in I86I, the so-called grande brigantaggio ["great brigandage"] spread in the south of continental Italy. Brigand violence was not new in the region, but in the context of regime change it developed into a brutal conflict. Brigand gangs employed murder, kidnapping, theft, and property destruction and were strongly linked to legitimist forces that sought to restore the Bourbon Francis II to the throne of the Kingdom of the Two Sicilies. The new Italian army, equipped with exceptional powers, repressed brigandage with ferocity and by 1865 the unrest had effectively ended in most regions in the south of the peninsula. ${ }^{6}$ In Ireland, the r 860 s witnessed a limited outbreak of agrarian violence and also the rise of the republican separatist movement, the Fenians, who attempted rebellion in 1867 . In the years I879-I882, agrarian protest broke out on an endemic scale, prompted by the European crisis in agricultural prices and coordinated by nationalists. The organization for land reform that emerged - the Land League - became one of the most formidable and effective social movements in modern Irish history. ${ }^{7}$ In satirical cartoons, Italian brigands and Irish agrarian agitators were

4. Alberto Mario Banti, La nazione del Risorgimento: Parentela, santità e onore alle origini dell'Italia unita (Turin, 2000), pp. 37-53. See also Silvana Patriarca and Lucy Riall (eds), The Risorgimento Revisited: Nationalism and Culture in Nineteenth-Century Italy (Basingstoke, 20I2).

5. Maurizio Isabella, "Review Article: Rethinking Italy's Nation-Building I 50 Years Afterwards: The New Risorgimento Historiography”, Past and Present, 2 I 7 (201 2), pp. 247-268, 267. See also Oliver Janz and Lucy Riall (eds), "Special Issue. The Italian Risorgimento: Transnational Perspectives", Modern Italy, I9 (2014), pp. I-92.

6. Daniela Adorni, "Il brigantaggio", in Luciano Violante (ed.), Storia d'Italia. Annali, I2. La criminalità (Turin, 1997), pp. 283-319, 288; Franco Molfese, Storia del brigantaggio dopo l'Unità (Milan, 1964), p. 385 ; Tommaso Pedio, Brigantaggio meridionale, I806-I863 (Cavallino di Lecce, 1987).

7. Donald Jordan, Land and Popular Politics in Ireland (Cambridge, 1994), pp. 197-313; Samuel Clark, The Social Origins of the Irish Land War (Princeton, NJ, 1979). 
portrayed as internal enemies of the state and, reminiscent of the perceptions described in Weber's classic account of rural France, the regions they inhabited were seen as seditious and backward, and required thorough reform through the introduction of civilizing values. ${ }^{8}$

The advantages of a comparative approach to satirical cartoons of peasants are twofold. First, as Eugenio Biagini has suggested, ${ }^{9}$ comparing how peripheral regions were portrayed in satirical magazines produced in metropolitan cities demonstrates difference, but also similarities in how societies responded to social unrest and how stereotyped images were packaged. ${ }^{10}$ Second, the comparative cases interplay and inform each other. I argue that cartoonists in Britain and Italy drew from a shared transnational repository of stereotypes regarding poverty, indolence, violence, and Catholicism when depicting unrest in Ireland and the mezzogiorno. In her study of Risorgimento literature and correspondence, Silvana Patriarca has demonstrated how patriots' attitudes toward the south represented a form of internalizing negative stereotypes about Italian national character that circulated in northern Europe, particularly England, in the nineteenth century. ${ }^{\text {II }}$ Cartoons of brigands also had an important function in this. At the same time, the strategies they employed held comparable details to depictions of Irish agitators in London-based satirical magazines. Cartoons were used to articulate visually social prejudices that held some national peculiarities, but were significantly rooted in a broader European context.

London-based satirical magazines have generated an extensive historical debate that has centred on questions of racialization and the ape-like features that were frequently attributed to Irish people in cartoons. In the most comprehensive study, Michael de Nie has contended that anti-Irish feeling was rife in political cartoons, but this prejudice was based on varied factors including religion and class, as well as ethnicity. ${ }^{\mathrm{I2}}$

8. Eugen Weber, Peasants into Frenchmen: The Modernization of Rural France, I870-19I4 (London, 1977).

9. Eugenio Biagini, British Democracy and Irish Nationalism $1876-1906$ (Cambridge, 2007), pp. $25-26$.

I0. Turin was the capital of the Kingdom of Italy from I86I-I865, and Florence from I 865-I87I. There is a longstanding scholarship in Italian historiography on how discourses of the periphery related directly to the equation of "southernness" with "backwardness". See John A. Davis, "Casting off the 'Southern Problem': Or, the Peculiarities of the South Revisited", in Jane Schneider (ed.), Italy's "Southern Question": Orientalism in One Country (New York, I998), pp. $205-224$.

I I. Silvana Patriarca, Italian Vices: Nation and Character from the Risorgimento to the Republic (Cambridge, 2010); Antonino de Francesco, La palla al piede: Una storia del pregiudizio antimeridionale (Milan, 2012).

I2. Michael de Nie, The Eternal Paddy: Irish Identity and the British Press 1798-I882 (Madison, WI, 2004), p. I3. See L. Perry Curtis, Anglo-Saxons and Celts: A Study of Anti-Irish Prejudice in Victorian England (Bridgeport, CT, 1968), published in a rev. edn as Apes and 
In contrast, Italian satirical magazines from the era of brigandage remain neglected, but they provide an important, additional perspective on Italy's "southern question" that complements research on how pejorative attitudes toward the south developed in illustrated newspapers after $1870 .^{13}$

Cartoons do not provide a transparent view of contemporary attitudes and could be shaped by artists' personal prejudices and the conventions of the time. Yet, as Peter Burke has maintained, "conventions filter information about the outside world but do not exclude it". ${ }^{14}$ For the humour in cartoons to work, De Nie has argued, the artist and reader must share common cultural preconceptions. And since they were "only joking", cartoonists could "publicly express anxieties and animosities that were often frowned upon". ${ }^{\text {Is }}$ This article focuses on a select number of representative cartoons, by a variety of artists and from a number of magazines, to identify similarities and differences. Comparing images of rural rebels demonstrates the significance of gender and class prejudices and how they were interconnected in understandings of "manhood" and its opposite: dependency.

Certain characteristics made peasants suitable only for minor roles in the modern nation and liberal capitalism. The rural inhabitants of both Ireland and the mezzogiorno were members of powerful European states, the United Kingdom and Italy, yet they simultaneously lived in circumstances with colonial aspects. The Irish case was more explicitly colonial, but aspects of Italian unification arguably resembled a northern conquest of the continental mezzogiorno, which was subsequently administered by policies determined in distant cities by officials with little understanding of the region. ${ }^{16}$ Both Ireland and southern Italy held characteristics of what has been termed internal colonialism, the subordination of one

Angels: The Irishman in Victorian Caricature (Washington DC, 1997); R.F. Foster, Paddy \& Mr Punch: Connections in Irish and English History (London, 1993), pp. 171-194; Henry Miller, "The Problem with Punch", Historical Research, 82 (2009), pp. 285-302; Peter Gray, "Punch and the Great Famine", History Ireland, I (1993), pp. 26-33; Sheridan Gilley, "English Attitudes to the Irish in England, I780-1900", in Colin Holmes (ed.), Immigrants and Minorities in British Society (London, I978), pp. 8 I-I Io.

I3. An exception is Brigantaggio, lealismo, repressione nel Mezzogiorno, I860-I870 (Naples, 1984). On the illustrated press and the south see Nelson Moe, The View from Vesuvius: Italian Culture and the Southern Question (Berkeley, CA, 2002), pp. I87-223; John Dickie, Darkest Italy: The Nation and Stereotypes of the Mezzogiorno I860-1900 (Basingstoke, I999), pp. 83-I 20; Schneider, Italy's “Southern Question”.

I4. Peter Burke, Eyewitnessing: The Uses of Images as Historical Evidence (London, 2001), p. 184 .

I5. De Nie, The Eternal Paddy, p. 34 .

I6. For an overview of the historiography on colonialism and the mezzogiorno see Enrico Dal Lago, "Italian National Unification and the Mezzogiorno: Colonialism in One Country?", in Róisín Healy and Enrico Dal Lago (eds), The Shadow of Colonialism on Europe's Modern Past (Basingstoke, 2014), pp. 57-72. 
region in a larger state dominated by people from another region. ${ }^{17}$ By comparison, however, derogatory portrayals of ethnic difference featured more explicitly in London-based cartoons of the Irish.

\section{CARTOONS AND THE “GREAT BRIGANDAGE”, 1861-1865}

Satirical magazines began to circulate in Europe in the 1830 . The Parisian Le Charivari started in 1832 and the London-based Punch in I84I, and the following decades saw the emergence of several more titles in London such as Fun (I 86I), Judy (I 867), and Funny Folks (I 874). In Italy, the main satirical magazines were established in I 848 and filled a clearly polemical function. Il Fischietto, Turin (“The Whistle”), Il Lampione, Florence ("The Lamppost"), L'Arlecchino, Naples, ("The Harlequin”), Lo Spirito Folletto, Milan ("The Elfin Spirit") and Il Cassandrino, Rome were all established in that year and, despite some interruptions, most survived to continue publishing during the following decades. Little is accurately known about their sales and circulation, though in this period Italian newspapers generally held lower readerships relative to English and French ones. ${ }^{18}$ Geographical disparities in Italian literacy rates, particularly between northern and southern regions, indicate that the circulation of these magazines, as with the press more generally, was regionally biased. Their readers belonged to the well-educated, urban middle classes. At the same time, the high number of titles indicates that satirical magazines were popular and improvements in reproduction technology and mass communication allowed them to reach a growing and significant readership. Increased circulation was facilitated by the dismantling of borders and the easing of censorship that came with unification. ${ }^{19}$

The proliferation of pejorative images of the mezzogiorno intensified following the creation of the Kingdom of Italy in I86I and the spread of brigandage. This was a decisive period in the shaping of relations, the "first massive encounter between north and south", and one where stereotypes about the mezzogiorno shaded the views of political and military officials. ${ }^{20}$ Perceptions of brigandage, John Dickie has argued, "influenced the construction of a barbaric, irrational South", where violence was

17. John R. Chávez, "Aliens in Their Native Lands: The Persistence of Internal Colonial Theory", Journal of World History, 22 (201 I), pp. 78 5-809; Michael Hechter, Internal Colonialism: The Celtic Fringe in British National Development, 2nd edn (London, 1999).

I 8. It was not until i 884 that an Italian daily, Il Secolo, reached the circulation figure of I 25,000; Michele Giordano, La stampa illustrata in Italia: dalle origini alla Grande Guerra (Turin, I983), p. 83; Franco Della Peruta, "Il giornalismo dal i 847 all'Unità", in Alessandro Garrone and idem, Storia della stampa italiana (Rome, I979), II, pp. 247-569, 491, 50I.

19. Giordano, La stampa illustrata, p. 81; Lucy Riall, Garibaldi: Invention of a Hero (New Haven, CT, 2007), pp. 88, I35-1 36.

20. Moe, View from Vesuvius, pp. 160-161. 
always a form of criminality, an expression of personal vendettas rather than of political grievances. ${ }^{21}$ Italian officials saw brigandage as a symptom of social deprivation and backwardness and, empowered by emergency legislation, they employed severe strategies of repression during the years I 86 I-I 865 that brought brutal consequences. ${ }^{22}$ In one notorious case, the army retaliated to the killing of forty-one soldiers in the village of Pontelandolfo in Campania by indiscriminately massacring several hundred villagers. ${ }^{23}$ The description of an infectious disease being treated by a surgeon constituted a common metaphor for visualizing the intervention of the Italian army in the south. ${ }^{24}$ When martial law was proposed for southern regions in I863, the Florence-based Nazione declared that opposing the legislation "would be the same as wanting to cure an illness without removing the cause that nourishes it, therefore ultimately maintaining it". ${ }^{25}$

After unification the circulation of satirical magazines grew and they were increasingly used as overt instruments to communicate national cohesion and shape public opinion among urban middle-class readerships. ${ }^{26}$ If Punch was the "London Charivari", Il Fischietto was the Italian version. The leading satirical magazine in the country, its artists included some of the most celebrated of the period, particularly the Turin-born Casimiro Teja and the editor, Francesco Redenti, from Emilia-Romagna. In the i 850 S Il Fischietto claimed a circulation of about 3,000, but the readership increased in the $\mathrm{I} 860 \mathrm{os}$. The magazine took aim at a wide variety of targets, including government ministers, yet it was decidedly liberal and anti-clerical in tone and generally depicted Cavour, Ricasoli, and often Garibaldi in a positive light. ${ }^{27}$

In Il Fischietto brigands were far removed from any ideal Robin Hoodtype figure, and distorted images became part of an exaggerated narrative of a south characterized by Bourbon reactionaries, criminal violence, and clerical power. In Figure I, Francesco Redenti portrayed the allegorical "Italia" leading a stream of brigands out of the Kingdom of Italy. Italia's physical form resembles the geographical outline of the new

21. Dickie, Darkest Italy, p. 29; De Francesco, La Palla al Piede, pp. 92-I 3.

22. For an analysis of this legislation, and a brief comparison with Irish coercion acts, see Roberto Martucci, Emergenza e tutela dell'ordine pubblico nell'Italia liberale. Regime eccezionale e leggi per la repressione dei reati di brigantaggio I 86 I-I 865 (Bologna, I980), pp. 57-66. 23. Roberto Martucci, L'Invenzione dell'Italia unita: I855-I864 (Milan, 1999), pp. 287-296.

24. Moe, View from Vesuvius, p. 172.

25. La Nazione, 20 December I 863.

26. Giordano, La stampa illustrata, p. 8I.

27. Carlo A. Petrucci, La caricatura italiana dell'Ottocento (Rome, 1954), pp. 37, 55-62; Della Peruta, "Il giornalismo dal I 847 all'Unità", pp. 3 I9, 50I; Giordano, La stampa illustrata, p. 73. On anti-Catholicism and satirical magazines see Manuel Borutta, "Anti-Catholicism and the Culture War in Risorgimento Italy", in Riall and Patriarca, The Risorgimento Revisited, pp. I9I-2I3, I97-200. 


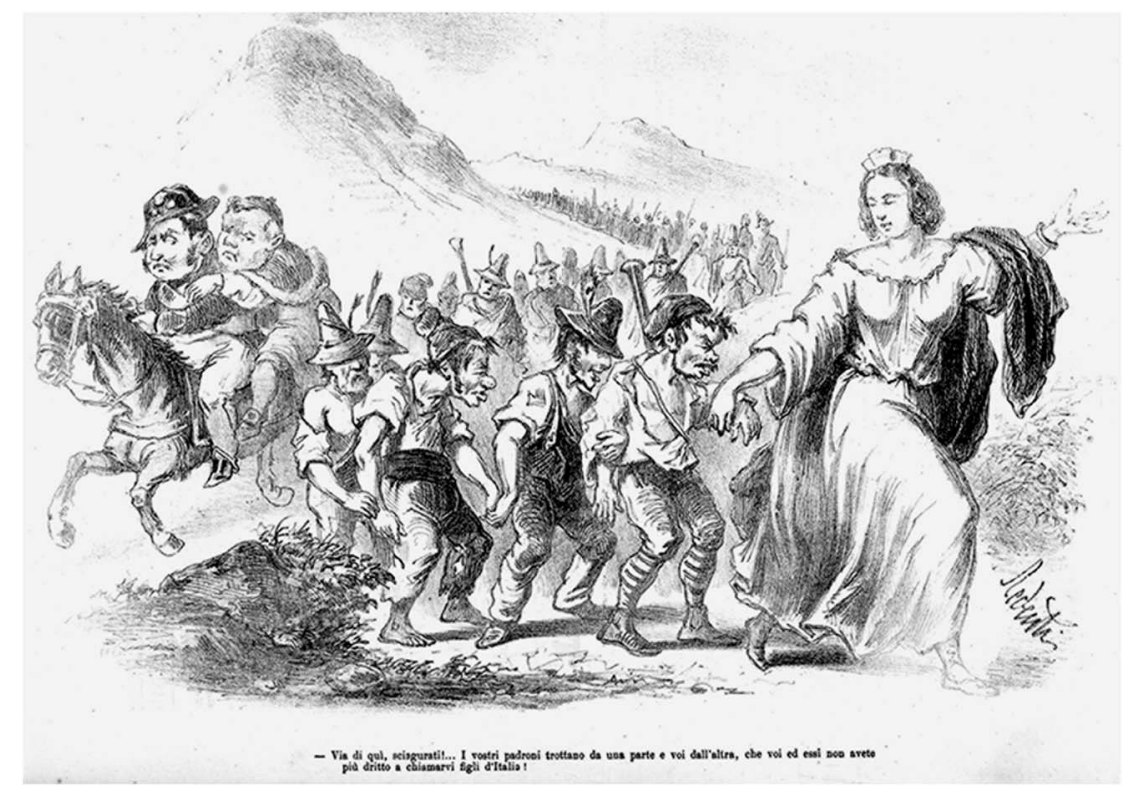

Figure r. "Via di qui, sciagurati!" [Away from here, wretches!], Il Fischietto, i 8 July i86i. Biblioteca Nazionale Centrale di Firenze and Ministero dei Beni e delle Attività Culturali e del Turismo, Italy. Used with permission. Further reproduction is not permitted.

nation-state. The brigands are infantilized, resembling characters from a fairy tale, or children, who offer no resistance as she pulls them out of the country and away from the manipulating Pope Pius IX and Francis II, who are escaping on horseback. The brigands are also drawn with hunched bodies and deformed features, which one study found to "border on racism". ${ }^{28}$ Ultimately they are passive beings; without Italia, the Pope, or Francis to lead them they would be lost, and the image draws on Bruegel's renaissance painting, The Blind Leading the Blind. ${ }^{29}$ The idea of moral failure is central to their predicament. The caption states: "Away from here, wretches! Your masters trot along on one side and you on the other side, both you and they no longer have the right to call yourselves sons of Italy!”. The brigands' unmanly violence and dependency on the Papacy and Francis II have ultimately excluded them from membership of the new nation.

Brigandage assumed different characteristics in different regions of the south, and often entailed small-scale civil wars between localized political and economic interest groups. Brigands did not directly agitate for land 
redistribution or revolutionary goals, but the pervasive violence was unquestionably an expression of profound dissatisfaction with rural hardship, food shortages, and opposition to a perceived illegitimate state. ${ }^{3 \circ}$ Cartoonists, however, focused mainly on brigands' links to the papacy and legitimist elements. In I86I the Catalan general Josep Borges landed in Calabria, planning to reclaim the throne for Francis II with the help of the famed brigand leader, Carmine Crocco. By the end of the year, however, Crocco had separated from Borges, and the latter was ultimately discovered and executed by the Italian army. This and similar episodes fed cartoonists' visualizations of brigands as the dupes of Bourbon legitimists, their foreign supporters, and the Papacy - the troika determined to weaken the new nation.

Brigands' dependency on conniving clerics regularly featured in cartoons. In Figure 2, by Turin-born artist Ippolito Virginio, five brigands play around the feet and lap of an opulent and overfed Pius IX. Armed with miniature shotguns, they appear as mythological dwarves or mischievous children, but also as naïve cat's paws about to be manipulated by a patriarchal Pope for his own self-interest. A fairy-tale-like quality is again present, evoking an infantile atmosphere in the scene. The caption accompanying the image quotes a verse from the illustrious Tuscan poet Vincenzo da Filicaja about motherhood, offering a reminder of high Italian culture, and also reinforcing the paternal relationship between Pope and brigand: "Like a mother, he [i.e. the Pope] looks at his children with merciful eyes, and is consumed with love at the sight of them. And kisses one on the forehead, and embraces one to the chest [...]'. ${ }^{\mathrm{I}}$ This image, similar to the others included here, accentuated the brigands' lack of manhood.

In her biography of Garibaldi, Lucy Riall has observed how "conflict in the Italian peninsula was re-narrativised as popular melodrama" in literature and theatre..$^{32}$ Similarly, these artists' cartoons represented a visual narrative in which heroes and villains of brigandage entered and exited the stage at different intervals. Cartoons rarely, if ever, depicted the brigand alone, and typically revolved around a variation of three characters: first, the brigand; second; a representative of the Catholic Church or Pope Pius IX himself; and third, a Bourbon loyalist, whether Francis II, or one of his external supporters, such as General Borges or Napoleon III. Interestingly, Pius IX appeared far more frequently than Francis II, suggesting that the Papacy was perceived as the greater threat to the political stability of a united Italy.

30. Salvatore Lupo, L'unificazione italiana. Mezzogiorno, rivoluzione, guerra civile (Rome, 201 I), pp. 99-I 29; Molfese, Storia del brigantaggio, passim.

31. "Qual madre, i figli con pietoso aspetto; Mira, e d'amor strugge a lor davante; E un bacia in fronte, ed un si stringe al petto. Ed uno tien sui ginocchi, un sulle piante [...] Filicaia, La Provvidenza."

32. Riall, Garibaldi, p. I35. 


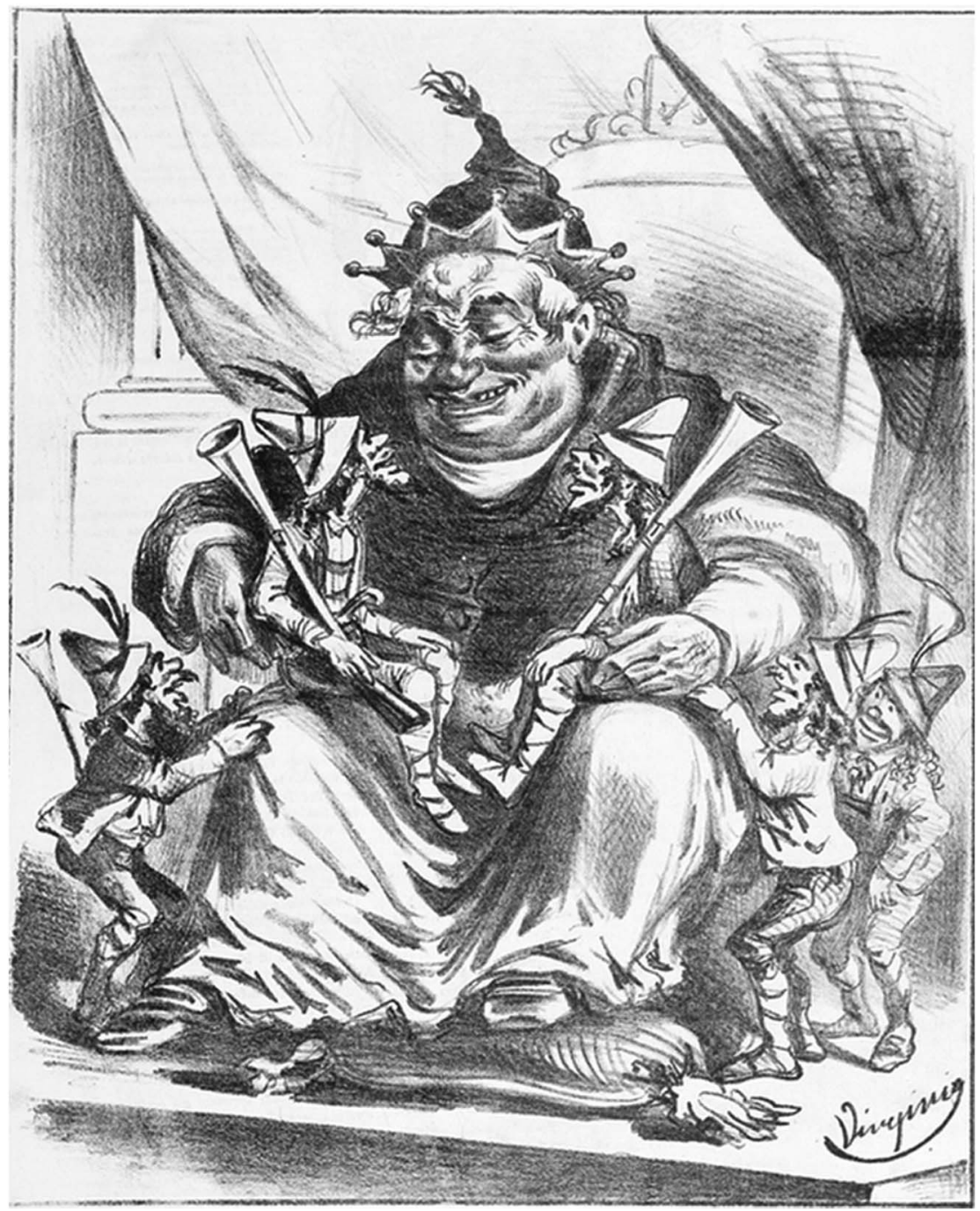

Figure 2. Il Fischietto, 24 May i 862.

Biblioteca Nazionale Centrale di Firenze and Ministero dei Beni e delle Attività Culturali e del Turismo, Italy. Used with permission. Further reproduction is not permitted.

Similar to Il Fischietto, the Pope was a central character in Il Lampione's cartoons. Figure 3 - entitled "Here is the only way the Pope-King can enter paradise!" - was drawn by Adolfo Matarelli and demonstrates the differing, and richer, artistic style of the Florentine Il Lampione when compared to Il Fischietto. The former magazine was of a similar moderate-liberal direction, though held a somewhat more well-heeled readership. It employed the 


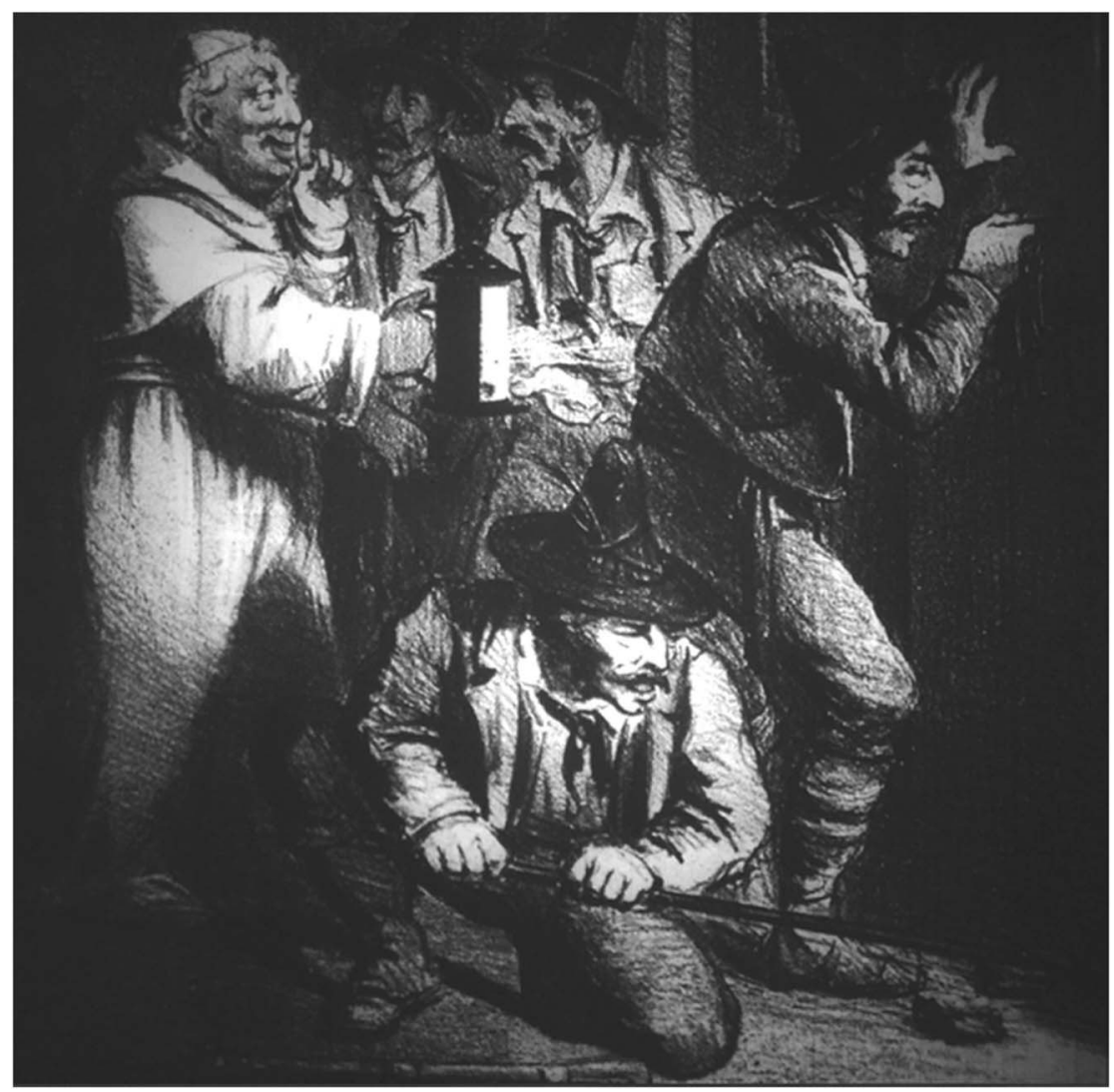

Figure 3. "Ecco l'unico modo con cui il Papa-Re potrà entrare in paradiso!" [Here is the only way the Pope-King can enter paradise!], Il Lampione, 24 October I863.

Biblioteca Nazionale Centrale di Firenze and Ministero dei Beni e delle Attività Culturali e del Turismo, Italy. Used with permission. Further reproduction is not permitted.

well-known Tuscan artists Matarelli and Angiolo Tricca, and was edited by Collodi, the pen-name of Carlo Lorenzini, who later found international fame with his fairy tale Pinocchio. ${ }^{33}$ In the cartoon, Pius IX stands with a torch alongside four brigands outside the gates of heaven, and they struggle to open the door. With a wry smirk the Pope whispers that he sold the original golden keys to maintain their actions, and now urges them to quietly break the lock so they may enter. In the caption, St Peter shouts to God that thieves are at the gates, who responds, "I know them".

33. Martina Allessio et al. (eds), Angiolo Tricca e la caricatura toscana dell'Ottocento (Florence, 1993), pp. I 56-I 599, 207-2 10, 2 19; Petrucci, La caricatura italiana, pp. 42-45; Della Peruta, "Il giornalismo dal I 847 all’Unità', p. 407. 
Unlike Figures I and 2, the brigands have regular, adult physical features. At the same time, they again lack agency and are merely doing the bidding of the wily Pope.

Cartoons represented a direct means of mass communication and contributed much to the visual idea of the south. In satirical magazines brigandage came to represent all that was bad about the south and focused broader stereotypes about southerners as violent and subservient people who required comprehensive reform before they could be included in the Italian nation. Cartoons in northern periodicals, one study has contended, were designed to "satisfy a certain type of educated bourgeoisie and their stereotypes" and they demonstrated "open disdain for the southern population, casually equated 'in toto' with brigands". ${ }^{34}$

True, there was not a single, monolithic south or a generic north: different worldviews and political programmes coexisted and competed across the peninsula. ${ }^{35}$ Neither were derogatory images of the south confined to publications in Turin or Florence, even though cartoonists there undoubtedly contributed more than others to homogenizing the views of a previously disparate northern readership toward events in which they played no part and in regions they were unlikely to visit. Satirical magazines were designed for the middle classes in large cities, primarily in the north, but also in the ex-Bourbon kingdom. After unification, many southern democrats, exiled in the north since I848, returned to the mezzogiorno and Marta Petrusewicz has demonstrated how during their exile, they had actively participated in the construction of negative stereotypes of the Kingdom of the Two Sicilies. ${ }^{36}$ After unification, the southern liberal press continued to advance pejorative images of the region and, in Naples, L'Arlecchino and the Abruzzo-born artist Melchiorre Delfico were enthusiastic caricaturists of brigands and clerics.

Along with Collodi and Teja, Delfico was one of the most vaunted caricaturists of nineteenth-century Italy and the principal artist for L'Arlecchino. In the i 870 , he was recruited by Punch and temporarily relocated to London. He considered himself a narrator as well as an illustrator and his work was unmistakably didactic and liberal, presenting a resolute argument that brigandage must be suppressed. ${ }^{37}$ Delfico's

34. Ferruccio Diozzi, "Una ricerca bibliografica”, in Brigantaggio, lealismo, repressione, pp. $37-39,39$.

35. John A. Davis, "The South and the Risorgimento: Histories and Counter-Histories", Journal of Modern Italian Studies, I9 (2014), pp. 53-61, 56-7; Marco Meriggi, "Legitimism, Liberalism and Nationalism: The Nature of the Relationship between North and South in Italian Unification", Modern Italy, I9 (2014), pp. 69-79.

36. Marta Petrusewicz, Come il Meridione divenne una questione: Rappresentazioni del Sud prima e dopo il Quarantotto (Catanzaro, 1998), pp. 105-158.

37. Maria Antonella Fusco, "L'iconografia", in Brigantaggio, lealismo, repressione, pp. 4I-43; Petrucci, La caricatura italiana, pp. 33-34. 


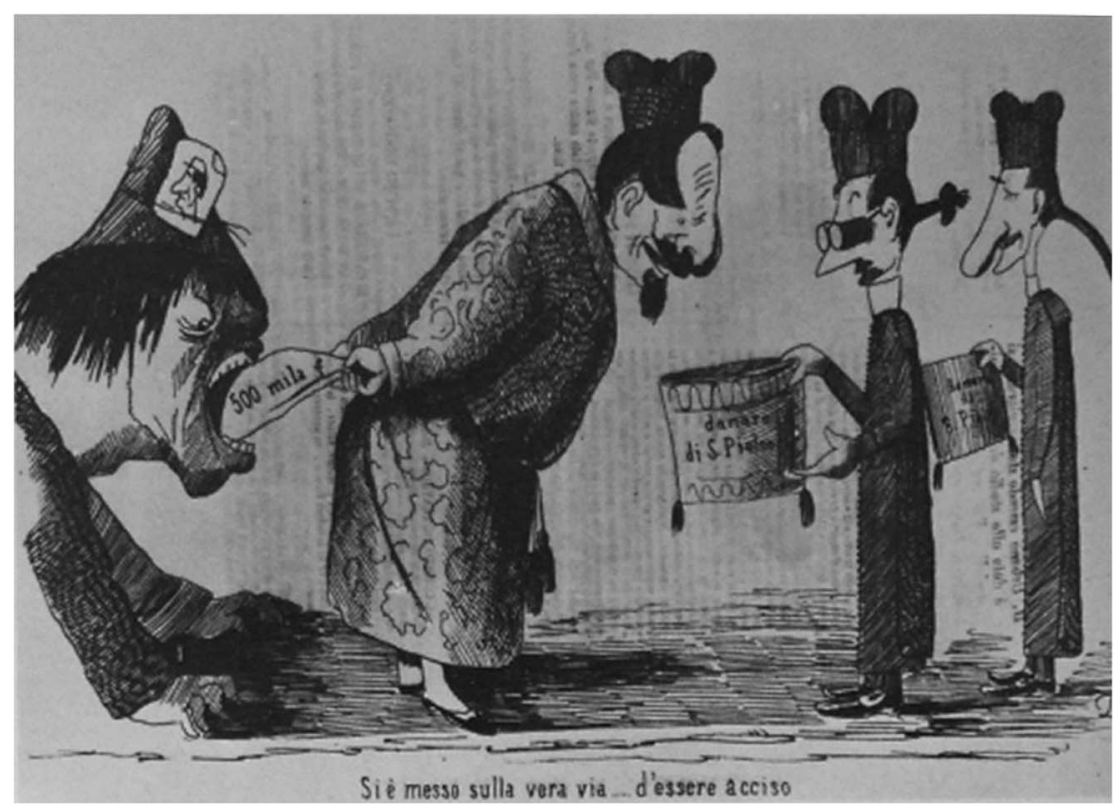

Figure 4. "Si è messa sulla vera via [...] d'essere acciso" [He is going the right way $[\ldots]$ to be taxed], L'Arlecchino, iо December I 862.

Biblioteca Nazionale Centrale di Firenze and Ministero dei Beni e delle Attività Culturali e del Turismo, Italy. Used with permission. Further reproduction is not permitted.

illustrations drew from a similar array of characters as those of his peers, albeit in more imaginative ways. In Figure 4, the brigand is depicted as a type of mythological giant or monster, yet he is also tethered to the authoritative figure of Napoleon III by a bag of money. At the centre of the image, the French emperor is caught between some priests who are collecting for Peter's Pence, and the brigand at his back who is chomping on a bag of 500,000 lira. The brigand's political sympathies are clearly marked by the image of Francis II tied to his cap. On the right, two priests are distinguished by their collection boxes and their ponytails, or codini, a word that also signifies conservative. The caption suggests Napoleon's role in the conflict is primarily to be taxed by reactionary elements in the south.

In each of the cartoons included above, drawn by four different artists in three magazines, the brigands are subservient to a padrone figure. Cartoons produced emasculated images of brigands where they represented the opposite of manhood, which was not simply cowardice or effeminacy, but dependency and lack of agency. They hold no sovereignty or control of their own circumstances and actions, but are the pliant instruments of manipulating clerics or interfering foreign rulers. 
Post-I86I the Risorgimento was not over, hence Italian patriots were sharply conscious of the work of regeneration and making citizens. Across nineteenth-century Europe "national character was a cornerstone of social thought" and Italian statesmen were acutely conscious of Italy's international image. ${ }^{38}$ Patriarca has demonstrated how Risorgimento nationalists internalized negative external stereotypes about Italian national character and reproduced them for the south. Virtuous characteristics were defined in large part by contrasting them with "Italian vice", primarily identified as ozio (indolence), subservience and cowardliness. ${ }^{39}$ Political cartoons reinforced the perception that, as Italian patriots had now decisively taken control of their own destiny, these vices were to be found only in the south among brigands and the people who supported or tolerated them.

Bourgeois concepts of manhood were central to ideas of the regeneration of national character. Lucy Riall has revealed how bold assertions of virilità [manhood] by Risorgimento nationalists sought to overcome stereotypes of Italian weakness, to halt moral decline, and revive national honour. Volunteering to fight and risk death for a democratic nation was particularly symbolic, as it constituted the "living proof that Italians were neither 'lazy' nor 'feminine' nor 'cowards', but strong and brave men, whose heroism, 'manhood' and success on the battlefield confirmed that national decline was caused by monarchs and not by their subjects". ${ }^{\circ} \mathrm{By}$ contrast, the "great brigandage" was an asymmetrical conflict and brigands did not engage in face-to-face fighting on the battlefield. Instead, they relied on guerrilla tactics and shelter from local populations, a form of war judged to be unmanly. Coming so soon after the regular, dynastic wars of unification, the irregular nature of the brigandage wars intensified hostility and generated images of brigands as barbaric and violent, but also as cowards who had forfeited their right to manhood and national membership through fighting a war with dishonourable, uncivilized tactics. ${ }^{4 \mathrm{I}}$

Caricaturists and magazines produced cartoons that were designed to connect with their readership's sense of humour and they reflect the sense of superiority and antipathy of the educated, urban bourgeoisie for the lower classes in the rural south. Perceptions of brigandage as a form of criminality was indicative of a class prejudice which viewed violence as a

\footnotetext{
38. Roberto Romani, National Character and Public Spirit in Britain and France, I750-19I4 (Cambridge, 2002), p. I; Maura O'Connor, The Romance of Italy and the English Political Imagination (New York, 1998), p. 9.

39. Patriarca, Italian Vices, pp. 23-26.

40. Lucy Riall, "Eroi maschili, virilità e nazione", in A.M. Banti and Paul Ginsborg, Storia d'Italia. Annali 22: Il Risorgimento (Turin, 2007), pp. 253-288, 263, 287; Patriarca, Italian Vices, pp. $20-50$.

4I. John A. Davis, "Le Guerre del Brigantaggio", in Mario Isnenghi and Eva Cecchinato (eds), Gli italiani in guerra. Conflitti, identità, memorie dal Risorgimento ai nostri giorni, vol. I: Fare l'Italia: unità e disunita nel Risorgimento (Turin, 2008), pp. 738-752, 749.
} 
social phenomenon when employed by peasants, but a political one when employed by the middle classes. Images of the south as a place dominated by criminal violence, backwardness, and corruption, Antonino de Francesco has contended, fed the perception that the bourgeoisie's preferred version of modernity had only arrived in one part of Italy, the north, while "the weight of the other part (the south) hindered forward momentum: in other words, a ball and chain" that impeded Italy's economic and civic development. ${ }^{42}$

Cartoons indicated that a firm, paternalistic approach was necessary in the south to end the unrest and bring recalcitrant children into line, but also to rescue southerners from papal control and traditional superstitious beliefs. In I86I, one northern official described southerners as "those wretched peoples without morals, without courage, without knowledge". Their character was a "mixture of credulousness and cunning that always delivers them into the hands of the greatest crooks". ${ }^{43}$ Such representations held paternalist, colonial aspects and gave moral justification to the exceptional legislation and brutal repression employed against brigands. The war became part of a mission to bring a subservient people out from under clerical influence and authoritarian rule and to regenerate a backward, violent region and incorporate it into the Italian nation.

\section{SOUTHERN ITALY, IRELAND, AND TRANSNATIONAL STEREOTYPES}

Ideas of national character and manhood advanced during the Risorgimento strongly echoed bourgeois ideals in Victorian England, which were highly gendered and which at times intersected with colonial attitudes. In I882, both the class and colonial aspects of these gendered ideals were sharply visible in The Times's obituary of Garibaldi, when it asserted that "Italians of the lower classes before 1849 were like Asiatics in their absence of manliness and self-respect. They could drive a stiletto home. They could scarcely look a superior in the face." Garibaldi, however, "set a fashion of masculine tenacity". ${ }^{44}$ Within Italian satirical magazines, similar suggestions were made about the lack of manhood among the lower classes in the south.

Italian patriots' self-conscious cultivation of national character was particularly sensitive to the views of English writers, statesmen, and travellers who toured the peninsula. ${ }^{45}$ In the eighteenth and nineteenth centuries the English middle classes held considerable affinity for Italy. A romanticized

42. De Francesco, La Palla al Piede, p. I3.

43. Diomede Pantaleoni, 2 I August I861, quoted in Moe, View from Vesuvius, p. I67.

44. The Times, 5 June 1882 .

45. For the writer Cesare Balbo, English character provided the model for industriousness and self-sufficiency, the opposite of indolence; Patriarca, Italian Vices, p. 32. 
image of the country was shaped by long visits on the Grand Tour and a passion for classical antiquity and the Renaissance. Post-I 848, enthusiasm for Italian independence grew substantially in England along with the view that a new generation of nationalists could overcome Italy's ills and develop a Piedmont-led liberal capitalist economy. The swell in support also reflected radical sympathies with oppressed nations and the appeal of the magnetic figures of Giuseppe Mazzini and Giuseppe Garibaldi, particularly after the former established himself as an exile in London in I $837 .{ }^{46}$ This support was reinforced by hostility toward the Papacy and the Kingdom of the Two Sicilies, which was stoked by Gladstone's widely read and damning report on Neapolitan prisons, and also driven by anti-Catholicism, intensified by massive Irish immigration to Britain after the Great Famine in the mid-nineteenth century. ${ }^{47}$

The views of Italy expressed in Victorian newspapers and travel literature reached beyond an English audience and Maura O'Connor has identified a cross-border dialogue that "serviced the cause of the Risorgimento in important ways". Risorgimento nationalists, and especially Garibaldi, were invested with all the "traits of a manly bourgeois Englishman", while southern Italians were stereotyped as "bandits and strumpets". ${ }^{4}$ Enthusiasm for northern Italian nationalism in English travel writing was shaded by uncomfortable descriptions of poverty, indolence, and corruption in southern regions. Such were the ills of the south, in fact, that comparisons with Ireland were regularly evoked.

The Irish, Roberto Romani has observed, were often considered by Victorians to have a "distinctive character" that marked them out from other European peasantries. ${ }^{49}$ Yet in Italy, travellers found many parallels that chimed with John Stuart Mill's assertion that it was "on the continent, and not in England, that we find anything like similarity of circumstances" with Ireland. ${ }^{50}$ In I 853 the English Catholic academic John Henry Newman wrote to a friend, "If you don't like the Irish, much less will you like the Italians", contending that anyone fond of "cleanliness" would not be at home there. ${ }^{5 \mathrm{I}}$ The art critic and reformer John Ruskin found "the misery of Dublin" when he stayed in Naples, but thought the latter city to be

46. Riall, Garibaldi, pp. 33-37, I42-144, 330-344.

47. There is a sizeable literature on Britain and the Risorgimento of which the following are a part: O'Connor, The Romance of Italy; Isabella, Risorgimento in Exile, pp. I I -2 I 2; Christopher Duggan, "Gran Bretagna e Italia nel Risorgimento", in Banti and Ginsborg, Storia d'Italia. Annali 22: Il Risorgimento, pp. 777-796; Denis Mack Smith, "Britain and the Italian Risorgimento", in Martin McLaughlin (ed.), Britain and Italy from Romanticism to Modernism (Oxford, 2000), pp. I3-3 I; C.T. McIntyre, England Against the Papacy, I858-186I: Tories, Liberals and the Overthrow of Papal Temporal Power during the Italian Risorgimento (Cambridge, I983), pp. 224-225.

48. O'Connor, The Romance of Italy, pp. 4, I88.

49. Romani, National Character and Public Spirit, p. 22 I.

50. John Stuart Mill, Chapters and Speeches on the Irish Land Question (London, I870), p. 99. 
"certainly the most disgusting place in Europe".52 When the American planter John Quitman toured Ireland on his way to Liverpool in I 839, he found that "the most contented class of people" he encountered "were the beggars. They rival the lazaroni [layabouts] of Naples in idleness and the enjoyment of mere animal existence." 53 In I857 the Irish-born social reformer and women's suffrage campaigner Francis Power Cobbe was disturbed by the poverty she encountered in the Kingdom of the Two Sicilies, contending that people there resembled "in ignorance, in squalor and in degradation the most wretched Irish who dwell in mud cabins amid the bogs, than any other people in Europe". ${ }^{54}$ In the I860s the Anglo-Irish writer Charles Lever worked in Italy as a British consul. His I 865 novel Tony Butler featured a fictional legion of 5,000 to 6,000 Irishmen who enlisted to fight against the new Kingdom of Italy and for the restoration of the Bourbon monarchy in the south. The legion soon broke up, however, with some joining Garibaldi and others becoming brigands in "the wilds of Calabria", which the protagonist compared to the "equally barbarous north of Ireland".5s Interestingly, the west was typically portrayed as the most brutal part of the island in the nineteenth century, but Lever evidently did not see it that way.

Irish parallels were not generally drawn with northern Italy; it was in the south that travellers found most similarities. Images of Italy in Victorian literature, but also in diplomatic reports and political discourse, regularly engaged in a process of "romantically recasting Italy as both self and other". ${ }^{6}$ On the one hand, northern Italian regions shook off repressive monarchical control, demonstrating determination, self-reliance, and a commitment to liberal capitalism, resembling England. On the other hand, the south was inhabited by dependent and lazy peasants who blindly followed Catholic clergymen - in short, a place that much resembled Ireland. When she travelled to the mezzogiorno the English

51. John Henry Newman, The Letters and Diaries of John Henry Newman, Vol. I s: The Achilli Trial, January 1852 to December I853 (Edinburgh, I964), p. 416; David Newsome, The Victorian World Picture: Perceptions and Introspections in an Age of Change (London, 1997), p. 96. 52. Quoted in Alexander Bradley, Ruskin and Italy (Ann Arbor, MI, I987), p. 52.

53. J.F.H. Claiborne, Life and Correspondence of John A. Quitman, Major-General, USA, and Governor of the State of Mississippi (New York, I860), p. 170, with thanks to Cathal Smith for bringing this source to my attention.

54. Francis Power Cobbe, Life of Francis Power Cobbe, 2 vols (Cambridge, I 894), I, p. 203. See also Jane Jordan, “The Peasant and the Picturesque in Ouida's Italy", in Alessandro Vescovi, Luisa Villa, and Paul Vita (eds), The Victorians and Italy: Literature, Travel, Politics and Art (Monza, 2010), pp. 6I-82, 7I-72; Ouida, A Village Commune (London, I882), p. 249.

55. Charles Lever, Tony Butler, 3 vols (Edinburgh, I865), III, p. I48; For a less stereotypical account of brigandage from the same period see William Moens, English Travellers and Italian Brigands, 2 vols (London, I 866).

56. O'Connor, The Romance of Italy, p. 2. 
travel writer and anthropologist Anne Buckland considered it to be the Ireland of Italy, and asserted that the residents of Campania, like in Ireland, were "quick, gay, careless, noisy and impulsive" in character, but they were also "vindictive, cruel, discontented, indolent; a people always ready to give trouble to their rulers, but never likely to improve their own condition". ${ }^{57}$ The rural working class in Ireland and Italy, then, contrasted strikingly with the industry, self-reliance, and thoughtfulness that many Victorians associated with the middle classes in England and northern Italy. The contrast combined class, as well as ethnic, prejudices, suggesting that traditional occupations and regional cultures rendered them ill-equipped to become productive contributors to the liberal capitalist economy.

English travellers' accounts of Italy frequently separated a deserving and undeserving poor. Southerners usually fell into the latter category and were considered to be responsible for their own miserable condition, views that strongly echoed political and media interpretations of the relationship between poverty and indolence in rural Ireland. During the Great Famine I $845^{-1} 852$ and in the following decades, assumptions about indolence and passivity became explanatory factors for distress and poverty. ${ }^{58}$ Indeed, images of the mezzogiorno in Victorian travellers' accounts can tell us more about their preconceptions than their actual impressions. The comparisons cited above suggest that some travellers already arrived in Italy with a predetermined picture of what their experience would be like, based on their assumptions about backwardness, dependence, and Catholicism in Ireland: they transferred negative traits from one rural region to another. In this view, the characteristics of the inhabitants in both places demonstrated their inability to improve economic circumstances and incapacity for self-government, justifying the British and Piedmontese presence in each region and attempts to modernize and maintain law and order.

As mentioned above, among Risorgimento patriots widespread interest in affairs in the United Kingdom existed, not least in the Irish question. In the i 840 s Camillo Cavour, who later became Italy's first Prime Minister, used the phrase "Italy's Irelands" when referring to the regions of the peninsula that presented the most difficulties in assimilation. In 1844 Cavour wrote a long essay entitled Thoughts on Ireland that advocated economic and agricultural reform. Similarly to Giuseppe Mazzini, however, Cavour believed that Irish problems would be best resolved within the United Kingdom. ${ }^{59}$ The republican federalist Carlo

57. Buckland, The World Beyond the Esterelles, II, pp. I63-I64.

58. See Enda Delaney, The Curse of Reason (Dublin, 2012), passim; De Nie, The Eternal Paddy, pp. $82-143$.

59. The Times, 2 I September I 866, 4 September i 873; Enrico Dal Lago, "Count Cavour's i 844 Thoughts on Ireland: Liberal Politics and Agrarian Reform through Anglo-Italian Eyes", in 
Cattaneo studied Irish agrarian reform extensively and sympathized with the Irish peasantry, but his writings also reflected his interest in the best means of assimilating Ireland into the United Kingdom; he did not think that the island was predestined for nationhood. ${ }^{60}$ Beyond intellectual interest in Irish reform, however, Irish stereotypes travelled and cartoons of Irishmen occasionally appeared in Italian magazines, along with people from other trouble spots of the British Empire, when artists sought to satirize British imperial problems.

In I865, a cartoon in Il Fischietto attributed to the Fenians - the Irish republican movement established in 1858 - the same vices that the magazine associated with southern Italians: indolence and violence. Hostility toward Irish republicans was likely stirred by the "Irish Papal Brigade" of I860, which comprised of 800 to I, 300 Catholic volunteers who were recruited in Ireland to defend the Papacy during the wars of unification in 1860 . Some of the brigade later became Irish nationalists. ${ }^{61}$ The caricature in Figure 5, by Virginio, represents something of an Italianized version of English humour. Several bayonets point at a somewhat ragged, yet relaxed Fenian, who is slouched against a wall, smoking a pipe, with his hands in his pockets. It certainly does not appear that he is about to start a rebellion. The caption reads "the English are sending a batch of toy guns to Ireland to remove the indolence of the 'Fainéants"'. The final word - Fainéants - is a French translation of the Italian word fannullone, which means idler, deadbeat, or literally, "do-nothing", and was chosen as a homophone for Fenians: such is the threat from this Fenian, the government need only send toy guns to Ireland. The cartoon indicates that stereotypes of the Irish travelled to Italy, via English literature and magazines, but also that these stereotypes drew from the same repository of characteristics as Il Fischietto's images of brigands.

These similarities are indicative of the transnational circulation of gendered stereotypes about class, indolence, and so-called moral failure in peripheral regions of Europe, and how they were applied to social and cultural situations that often differed considerably from each other. In mid-nineteenth century France, for example, homogenizing ideas of national character resulted in the country being divided into spheres of north and south, "one of which [the south] seemed inimical to social and economic progress". Stereotypes of indolent, undisciplined, and temperamental

Niall Whelehan (ed.), Transnational Perspectives on Modern Irish History (New York, 2014), pp. 88-105.

60. Martin Thom, "Great Britain and Ireland in the Thought of Carlo Cattaneo", in Franco Della Peruta and Carlo G. Lascita (eds), Carlo Cattaneo: $i$ Temi e le Sfide (Milan, 2004), pp. 387-429, 4I 2-429; Francesco Cheratzu (ed.), La terza Irlanda: gli scritti sulla Sardegna di Carlo Cattaneo e Giuseppe Mazzini, (Cagliari, I995).

61. George F.H. Berkeley, The Irish Battalion in the Papal Army (Dublin, 1929). 


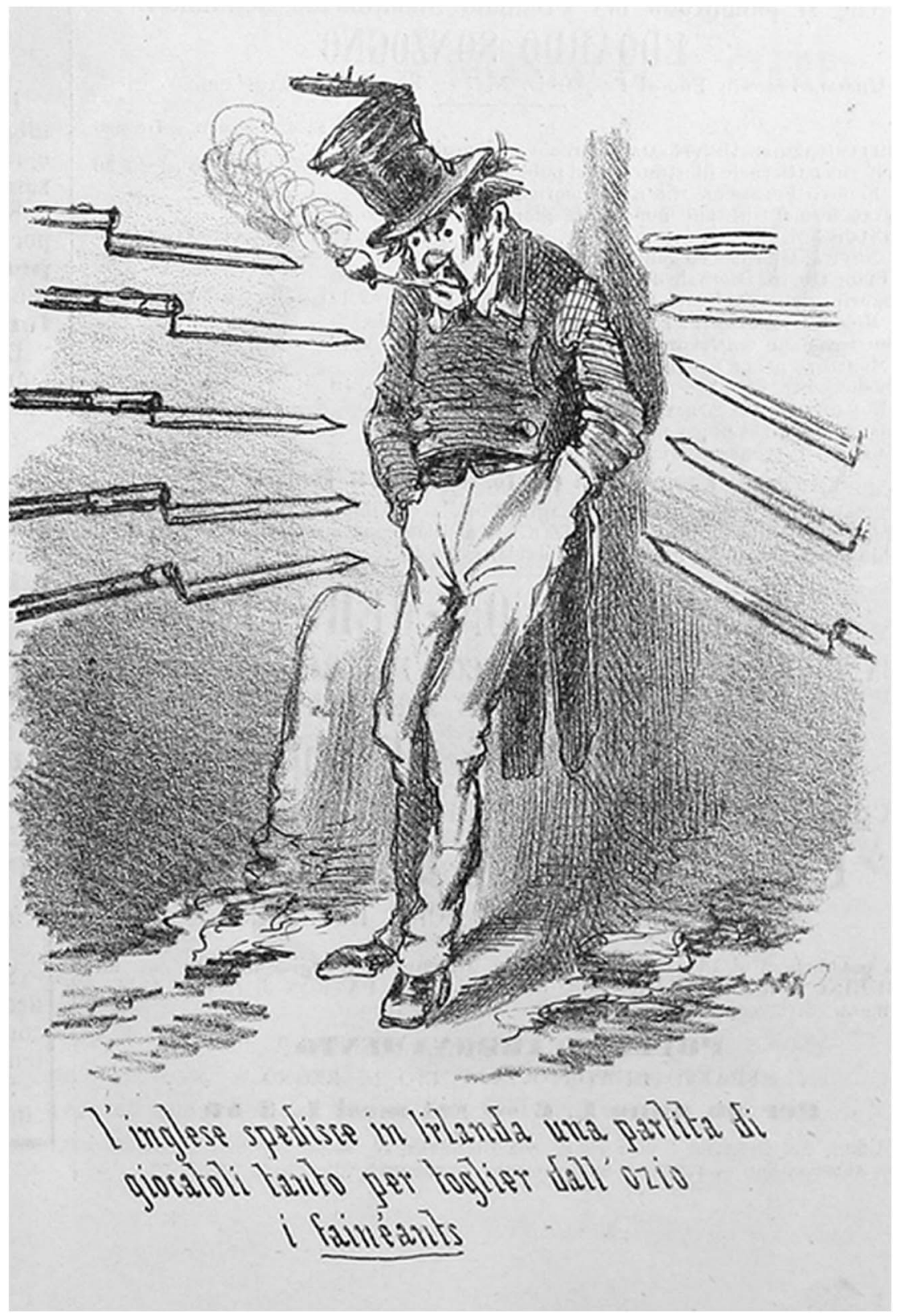

Figure 5. Detail from "I gusti degli elettori" [The preferences of the voters], Il Fischietto, 23 September I 865.

Biblioteca Nazionale Centrale di Firenze and Ministero dei Beni e delle Attività Culturali e del Turismo, Italy. Used with permission. Further reproduction is not permitted. 
"troublemakers" in the southern Midi region were regularly found in reports written by French officials, echoing the qualities attributed to the mezzogiorno and Ireland. ${ }^{62}$ It is in this transnational context that cartoons of rebellious peasants are best understood.

\section{CARTOONS OF IRISH REBELS IN COMPARATIVE PERSPECTIVE}

Contemporary comparisons between Ireland and southern Italy came to the fore in the London press during times of unrest and instability. When brigandage intensified in the I860s, The Times, an influential newspaper that viewed the Irish as inferior, commented that "the difficulty of suppressing the Brigandage of Southern Italy arises from the sympathy it finds among the honest and half-honest part of the population". This was a familiar scenario, or so the editorial claimed, as the ways in which communities in southern Italy sheltered the perpetrators of violent acts mirrored the situation in rural Ireland. From the 1760 s secret societies in Ireland employed intimidation, property destruction, and murder to regulate matters relating to land occupation, rents, and jobs. With names like Whiteboys and Ribbonmen, these underground rural societies saw themselves as the upholders of unwritten law in the face of transgressors. ${ }^{63}$ The authorities were frequently frustrated when they attempted to apprehend and prosecute the perpetrators, and often resorted to emergency legislation. The difficulties in policing violent crime in the wild Irish countryside led one editorial to declare,

[...] we have scarcely any right to censure the Italian government for its apparent inability to grapple with this enormous evil, when the strong arm of our own long established government has so often been defied in Ireland by an opinion that protects the most atrocious criminals [...]. The Italian peasant will take to the mountains as a brigand; the Irishman will plan an assassination, and both will be sure to find sympathy. It is this perverted public opinion that creates for two governments so different as those of Italy and England a difficulty of the same kind. ${ }^{64}$

62. Bernard Rulof, “There are Many Troublemakers' in the Midi: Imagining Society and Politics in Nineteenth-Century France", European Review of History/Revue Européenne d'Histoire, 20 (2013), pp. I-I9, 4.

63. James S. Donnelly, Jr, Captain Rock: The Irish Agrarian Rebellion of I $82 I-I 824$ (Cork, 2009), pp. 20-2 I, 174, 365; Samuel Clark and James S. Donnelly (eds), Irish Peasants: Violence and Political Unrest I780-I9I4 (Madison, WI, I983); Michael Beames, Peasants and Power: The Whiteboy Movements and their Control in Pre-Famine Ireland (Brighton, 1983).

64. The Times, 6 February 1863 . 
What was comparable in Ireland and Italy was not just the types of violence, but the character of the people who inhabited rural regions, who were perceived as having no inclination to comply with law and order. Rather, they sought to frustrate it. Indeed, Italy's work was only beginning: "Five centuries' rule have not yet assimilated or even tamed Ireland; it is no wonder if the Italians, after less than three years union, find the Two Sicilies such a hard uphill work for them." ${ }^{\text {65 }}$ In I87 I Punch suggested that the authorities in Ireland should learn from how the new Italian government repressed brigandage when considering solutions for unrest in Ireland. ${ }^{66}$ Articles in both The Times and Punch asserted that unrest in the south provided the moral justification for Italian unification and the firm stance taken by the new Turin government, and suggested that similar conditions in Ireland legitimized the Union. Ireland and the mezzogiorno were obstacles on the road to national modernity, and the challenge facing the governments of Turin and London was to effect painful but necessary policies to maintain law and order and reform society.

Parallels between violence in rural Ireland and Italy were also drawn in political debate. In I86I, when discussing Irish agrarian violence in parliament, the Earl of Leitrim declared that "there was only one other country in Europe where such a system prevailed, and that was Naples [sic]" ${ }^{67}$ When parliament debated the upturn in agrarian murders in the late i 860 s, the Anglo-Irish member William Gregory greatly exaggerated that the "reign of terror [...] was only equalled by the condition of Southern Italy a few years ago". ${ }^{68}$ Regional newspapers also observed how Irish agrarian violence was "a form of brigandage [...] the Italian banditti are, however, infinitely more respectable in numbers and in purpose than the Ribbonmen in Ireland". ${ }^{69}$ Some Irish nationalists drew parallels between the repressive measures employed in southern Italy and the use of emergency legislation in Ireland: When debating the I88I Coercion Act in parliament A.M. Sullivan remarked, "any man could govern with a state of siege, whether in Italy, in Ireland, or the House of Commons". ${ }^{\circ}$

In the 1860 s emergency powers (suspension of habeas corpus) were partially introduced in Ireland in reaction to the Fenian movement's plans for rebellion and also to a limited outbreak of agrarian violence. Later, during the Land War of I879-1882, rural violence erupted on a nationwide scale and resulted in two wide-ranging Coercion Acts in I88 I

65. The Times, 23 March 1863.

66. Punch, 22 April i87i.

67. Earl of Leitrim, House of Lords, Debate, I 2 February i86I, vol. I6I, cc. 332.

68. William Gregory, House of Commons, Debate [hereafter, HC Deb.], 27 February I871, vol. 204 , cc. IOI 3 .

69. Westmeath Guardian, 27 January 1870.

70. HC Deb., i I March I88 I, vol. 259, cc. 858; HC Deb., i० May i 875, vol. 224, cc. 4-7-8. 
and I 882. In i 879 the Irish Land League was established as an alliance of Fenians and moderate nationalists for the redistribution of land and political reform. Against the backdrop of severe distress, particularly in the west and north-west, the league swiftly developed into a mass movement that entailed civil disobedience such as boycotting, but also violence that targeted landlords, their agents, and tenants who rented land from which others had been evicted. Outbreaks of Irish agrarian violence were many times less deadly than the brigandage wars in Italy, yet these cases provide interesting comparators, not least for the ways in which the conflicts were imagined in satirical cartoons.

There were numerous similarities in the conventions of style used in London-based and Italian magazines. For example, the mythological many-headed hydra was frequently used to represent the dangers posed in each place: whether a Herculean figure fighting a hydra representing the Papacy, Bourbon loyalism, and brigandage, or an heroic Gladstone defending Ireland against the triple evils of "anarchy", "terrorism", and "sedition". ${ }^{\text {I }}$ Cartoons frequently depicted women or allegorical female figures, such as Hibernia, Italia, or Britannia, in need of protection from violent peasants or political agitators. ${ }^{72}$ There were also similarities in how republican nationalists were portrayed. Giuseppe Mazzini opposed the new constitutional monarchy in Italy and one cartoon in Il Lampione rendered him with a human head but a serpentine body, looking on at Garibaldi, Cavour, and Victor Emmanuel concluding a historic agreement to "make Italy". The image held clear similarities with the snake-like caricatures of Fenians in London magazines. ${ }^{73}$

In both countries, not all cartoons engaged in explicit negative stereotyping and satirical magazines generally expressed hopes for reform in Ireland and southern Italy, rather than considering them beyond civilizing, as was the case with some non-European peoples. London-based magazines often supported reforms in Ireland and acknowledged past injustices. Nonetheless, a number of historians have argued that the Irish peasantry was consistently constructed as the other, even in sympathetic London accounts. ${ }^{74}$

One of the most striking similarities to emerge from comparison between cartoons of brigands and Irish agitators is how frequently both were found wanting in many qualities of Victorian manhood, particularly self-reliance and individual sovereignty. ${ }^{75}$ In Figure 6 , by the artist

71. Il Lampione, I I September I860; Punch, s February I88 I; Judy, 7 September I 887.

72. Il Lampione, io June I862; Punch, I9 March I879; Punch, 29 October I88I.

73. Il Lampione 29 September i 860.

74. Romani, National Character and Public Spirit, p. 2 I4, De Nie, The Eternal Paddy, p. 268.

75. The cartoons included here are representative of the political satire published in Londonbased magazines, though not in Britain more generally. See Miller, "The Problem with Punch", p. 286. 


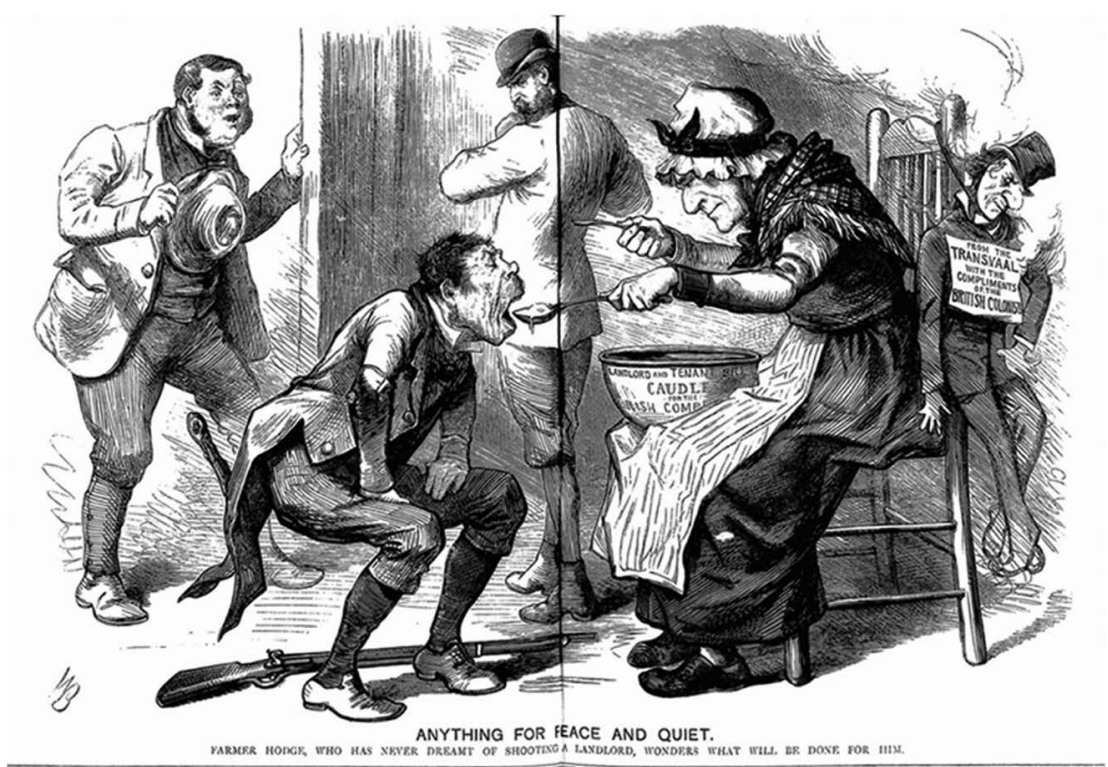

Figure 6. "Anything for Peace and Quiet”, Judy, I3 April I88 I.

National Library of Ireland. Used with permission.

William Boucher, the law-abiding Farmer Hodge, "who has never dreamt of shooting a landlord", looks on empty handed at a simianized Irish farmer receiving welfare in the form of the traditional medicinal drink caudle. As indicated on the bowl, the drink represents the i88 I Land Act, which aimed to address some of the Land League's demands for reform. Leaving his rifle on the ground, the farmer crouches down to take his spoonful of medicine from Gladstone, who is dressed as a peasant woman. The image evokes a mother-child relationship, and also plays on a time-worn stereotype of welfare and poverty that holds obvious class prejudices: the hardworking middle-class Farmer Hodge receives nothing, while his rowdy neighbour profits from the threat of violence, receiving government assistance. The simianized farmer represents the inversion of English manly character, he lacks self-reliance and depends on assistance from government, but is also somewhat cunning as he manages to survive while avoiding the hard work that Farmer Hodge engages in every day.

Bourgeois concepts of manhood in the Victorian era entailed qualities of independence, industry, moral duty, and self-control. These qualities were rooted in middle-class self-perception, representing an "external code of conduct, policed by one's peers", and a means of differentiating between men and their moral virtues. The working class remained relatively uninfluenced by these ideals and were perceived in the middle-class 
press as "roughs" who lacked restraint and self-control. ${ }^{76}$ During the Land War, Irish nationalists consciously appealed to notions of Victorian manhood. When touring Britain for the Land League, T.P. O'Connor declared that the movement had installed "into their people a spirit of manliness, a spirit of courage, a spirit of independence and of self-reliance". ${ }^{77}$ In I882, United Ireland quoted an editorial from The Times on the death of Garibaldi, which observed, "to him, moreover, Italy is indebted for an ideal of manliness and individual self-reliance, the qualities Italians most wanted". Yet, United Ireland observed, the same paper refused to recognize that the Land League was instilling the same qualities in Ireland..$^{78}$

Irish agitators, similar to brigands in Il Fischietto, were sometimes depicted as children or diminutive figures. In I 870, emergency legislation was passed to give authorities extra powers to deal with a series of agrarian murders in the Irish midlands. That year, a cartoon in Judy entitled "The Impatient Patient" (Figure 7) depicted Ireland as an overgrown child squirming in a chair, refusing to swallow medicine from Gladstone and a nurse. Similar to Figure 6, a gun, albeit a toy one, lies on the floor, along with a model church, an American cap, and a pig figurine. Again the parent-child relationship is evoked to represent Westminster's policies toward Ireland. ${ }^{79}$ Similar images were common. In I880, Funny Folks portrayed Ireland as a child being fed seditious mixtures by Irish Parliamentary Party leader Charles Stewart Parnell, in a cartoon that, De Nie has argued, drew on "two familiar themes: Ireland as a minor in need of a guardian and the unsuitability of Ireland's political classes to fulfil this role”. In I893, when the passage of the second Irish Home Rule act was underway, Punch depicted Gladstone nursing a baby wrapped in the bill. ${ }^{80}$ Occasionally British politicians and Gladstone himself were portrayed as babies or diminutive figures, as were liberal politicians in Italian magazines, but in these images they typically had the bodies of babies or children, but with adult faces and adult minds. ${ }^{8 \mathrm{I}}$ They differed from the more distorted physical features frequently found in caricatures of child-like peasants. In comparison, infantilized brigands appeared to a greater extent in Italian satirical magazines, particularly Il Fischietto, but cartoonists in Turin and London both emphasized the idea that paternal,

76. John Tosh, "Masculinities in an Industrializing Society: Britain, I800-1914", Journal of British Studies, 44 (2005), pp. 330-342, 335-336; Matthew McCormack (ed.), Public Men: Masculinity and Politics in Modern Britain (Basingstoke, 2007), p. 5.

77. Dundee Advertiser, Io December I 880. See also Joseph Valente, The Myth of Manliness in Irish National Culture, I880-1922 (Chicago, IL, 2010).

78. United Ireland, 10 June I882; The Times, 5 June 1882.

79. Judy, I6 March I 870.

80. Punch, 25 February i 893 ; The 1886 Home Rule Bill was also caricatured as wrapped around a baby in Judy, I4 April, 5 May, 9 and 30 June 1886; De Nie, The Eternal Paddy, pp. $225-227,258$.

81. For example, Judy, I4 April i880, 9 July I890; Punch, 22 May i880, 21 August I880. 


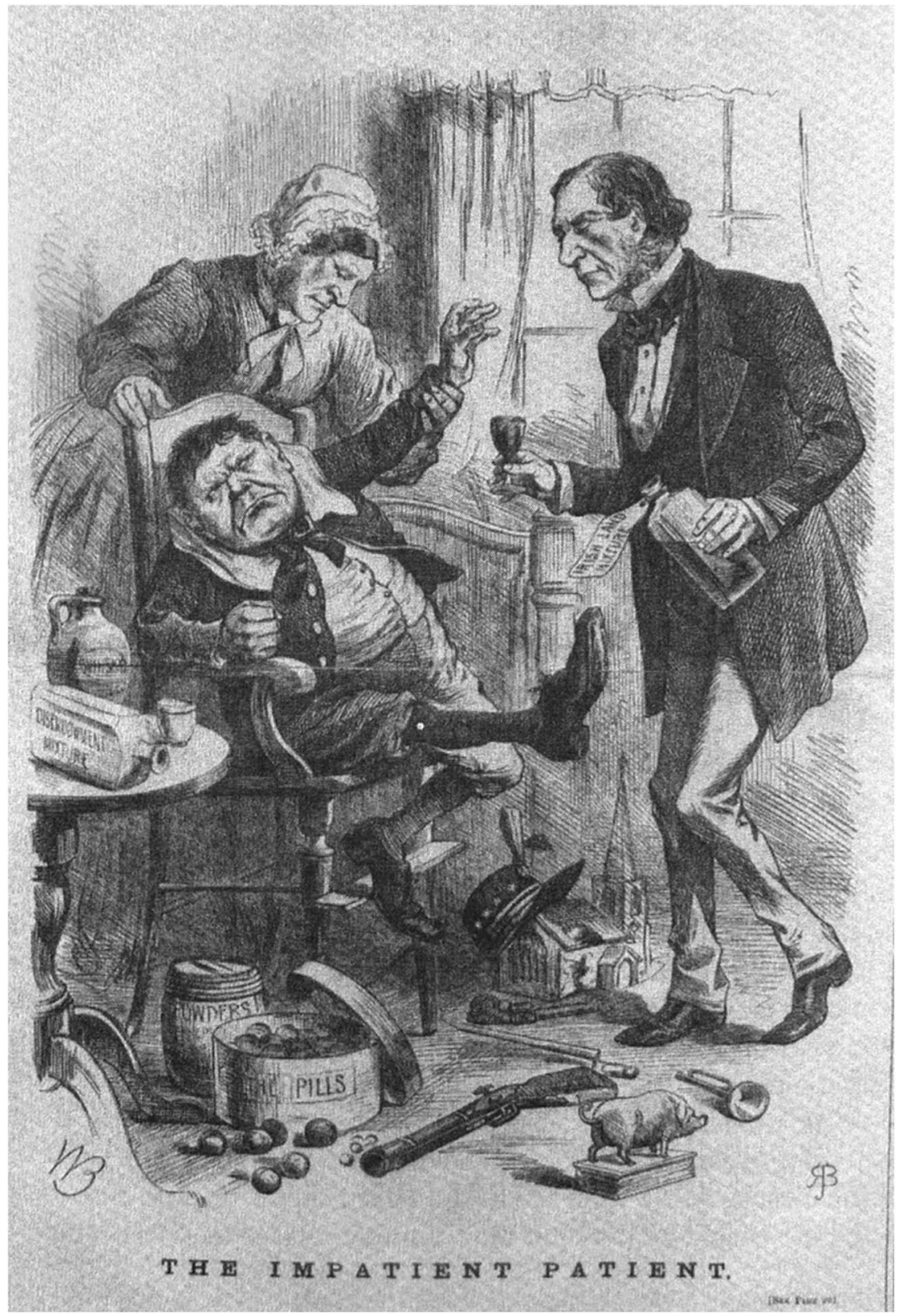

Figure 7. "The Impatient Patient”, Judy, I6 March I870.

National Library of Ireland. Used with permission. 
"cruel-to-be-kind" measures were ultimately to the benefit of the Irish countryside and the Italian mezzogiorno.

In contrast, Catholic clerics, and particularly the Pope, appeared to a much greater extent in cartoons of brigandage when compared with those of Irish agrarian violence. The Pope and the Papacy were perceived to represent a greater political threat in Italy, whereas in Ireland the Catholic hierarchy was a vocal opponent of agrarian violence and secret societies. While the temporal power of the Catholic Church was decreasing in Italy in the I860s, it was increasing in Ireland, and part of the government's approach to resolving social and political unrest entailed large concessions to Catholic institutional power, as with the I 869 Disestablishment Act. At the same time, clerical figures were not completely absent from cartoons. The Irish agitator in Figure 8, by Boucher, receives an open confession from a priest. His shotgun and hat lie against the wall, while he appears to drop some money into the cleric's left hand to gain absolution for a murder before he commits it. In the bottom section a landlord lies mortally wounded by a wall, evoking the frequent trope of unmanly violence: the cowardly assassin strikes from behind the wall and then runs away. In the top section, the assassin has clearly simianized features. The cartoon suggests that some members of the Irish Catholic clergy privately sanctioned agrarian violence, and occasionally profited from it.

\section{SIMIANIZATION AND COLONIALISM}

One of the more contentious aspects of Irish cartoons relates to questions of ethnicity. In his 1968 study of London satirical magazines, L. Perry Curtis highlighted the diffusion of Irish figures with such "ape-like features as the simous nose, long projecting upper lip, shallow lower jaw, and fanglike teeth", which he explained in the context of the development of scientific racism in the second half of the nineteenth century. ${ }^{82}$ This simianized "Paddy" caricature was not universal. The Graphic and Illustrated London News, for example, typically depicted Irish people with the same physical features as English people. In 1870 the Graphic spoke of "astonishing differences" between English and Irish people, but also maintained that "there really is nothing in the brain of a Celt which irresistibly impels him to landlord-shooting" ${ }^{83}$ Even in the London-based humorous magazines, the bestial Irishman was not omnipresent, and simianized facial features were also employed to illustrate European anarchists and nihilists, in order to personify visually political threats to order and stability. ${ }^{84}$

82. Curtis, Anglo-Saxons and Celts, p. 42.

83. The Graphic, 22 January I 870.

84. For example, see "A Fair Question”, Judy, 25 August i880; “A Poser for Pat”, Judy, I September I 880; “The Congress Of Revolutionists; Or, Lunatics At Large”, Judy, 27 July i88I. 


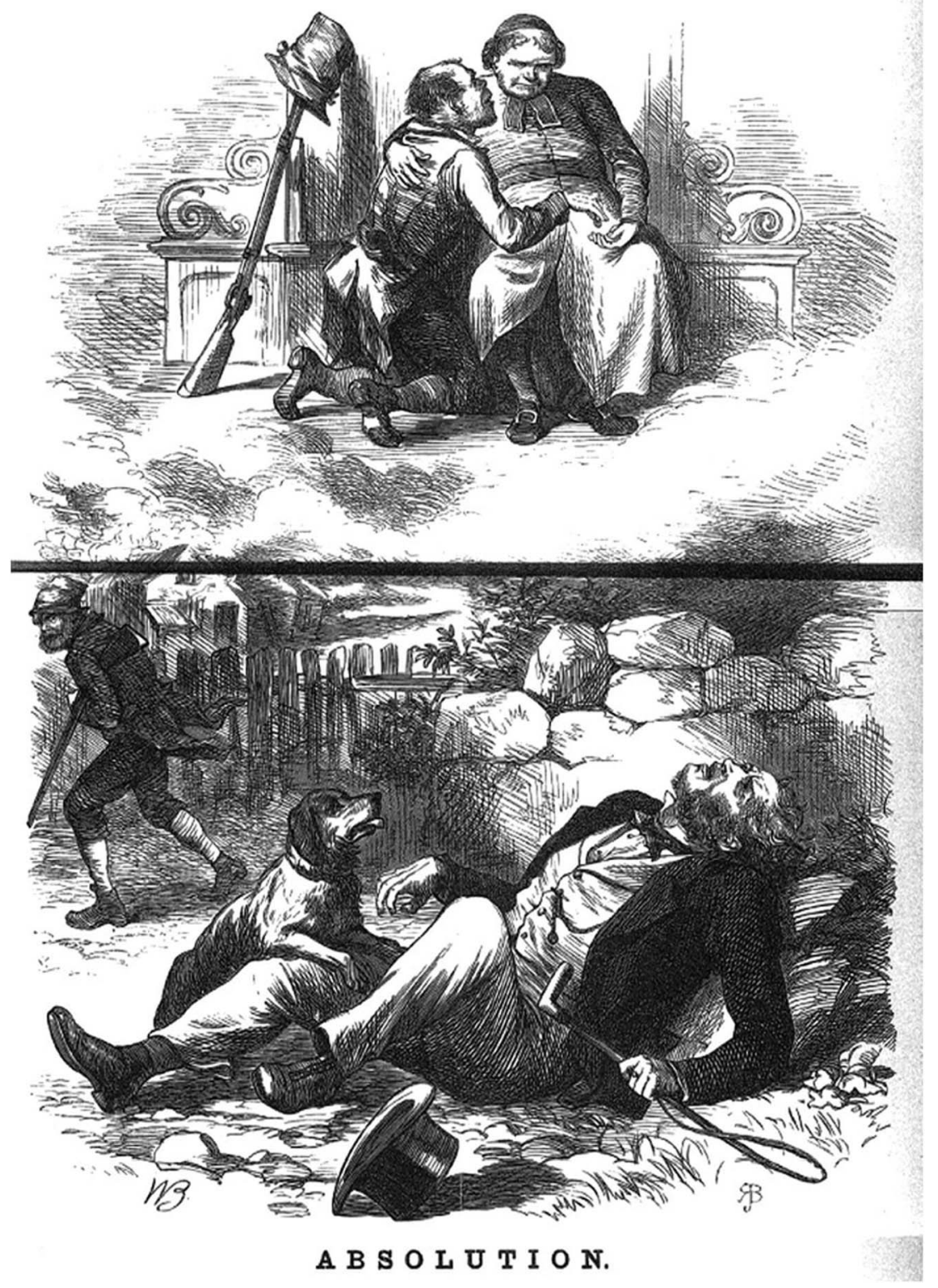

Figure 8. "Absolution”, Judy, 20 January 1869.

National Library of Ireland. Used with permission. 
During periods of unrest, however, and particularly during the Land War, the figures of simian and reptilian monsters became, in London magazines, primarily attached to Irish agitators and peasants. ${ }^{85}$

In contrast, the simianized brigand was unfamiliar in the magazines of Turin, Florence, or Naples. During the I880s, the Italian ambassador to the United Kingdom, Luigi Federico Menabrea, was a reader of Punch and $J u d y$ and occasionally attached caricatures, usually dealing with diplomacy, to his dispatches to Rome when he felt they nicely caught "the real situation". Menabrea, who had been a senior official during the brigandage wars and even briefly served as Prime Minister in the late I860s, kept a close eye on the Irish Land War and the government's attempts to legislate effectively on the land question. In I 879, a lengthy dispatch to Prime Minister Benedetto Cairoli regarding Ireland discussed how satirical magazines represented the situation, observing that, "[i]n England, mockery of the Irish is thriving, the English portray them as evil animals rather than human beings" ${ }^{86}$ The tone of the dispatch suggests surprise and unfamiliarity with the style of the caricatures.

Portrayals of Italian brigands as "evil animals" were far less common. Indeed, textual images of brigands, as described in studies by Dickie and Adorni, are arguably more brutalizing in the I860s than visual images. In Il Fischietto, Il Lampione, and l'Arlecchino brigands were typically represented as mythological figures, children, and dwarves. Sometimes caricatures related to a play on words: the brigand Chiavone, for example, whose name sounded like chiave [key] was often drawn in the physical shape of a key. On one occasion, Delfico drew the brigand Peretti with a pig-like snout, and as mentioned above, the dissident republican Mazzini was sometimes portrayed with a serpent's body. ${ }^{87}$ In Figure I, where the allegorical Italy leads brigands out of the country, one study found racist aspects in the "nightmarish physical deformations" of the brigands. ${ }^{88}$ Yet their physical attributes in this image are still essentially human. Drawing on a rich tradition of theatre and visual culture, Italian caricaturists regularly employed figures from the bible and Greek and Roman mythology to embellish their satire, but not from the jungle. Brigands' physiognomies rarely held reptilian or ape-like aspects and often were not visibly different from northern Italians, as in Figure 3 (where the Pope connives with four brigands outside the gates of heaven).

85. “The Rivals”, Punch, I 3 August I881; “At Last!”, Judy, 26 October I881; “The Irish Frankenstein", Punch, 20 May I 882.

86. "L'imitazione in Inghilterra é vivissima contro gli’Irlandesi che gl'Inglesi dipingono come animali malefici, anziche come uomini”; Luigi Federico Menabrea to Cairoli, I 8 and 25 November 1879, Archivio Storico Diplomatico, Rome, Moscati VI, b. I359.

87. L'Arlecchino, is December i86i; Il Lampione, 29 September I860.

88. Brigantaggio, lealismo, repressione, ${ }_{1860-1} 870$, p. I 83. 
In contrast, Irish agitators and peasants were frequently drawn as variety of animals: skunks and snakes, pigs and toads, monkeys and gorillas. In Figure 9 from Punch, John Tenniel drew the rural agitator as a heavily armed Caliban, based on the character from Shakespeare's The Tempest, who embodies the worst of agrarian violence, Catholicism, and Fenianism. This caricature represents one of the clearest examples of simianization, and it drew criticism in contemporary British newspapers when published. ${ }^{89}$ The brutish, ape-like agitator rages at Gladstone, who plays the character of Prospero, but also extends the palm of his left hand, asking for Gladstone's staff, which is marked "Irish Land Bill". Gladstone, undaunted, protects the barefoot Hibernia, again evoking the paternalist relationship between metropole and periphery. Similar examples of ape-like brigands were not evident in the Italian illustrated press.

Between the I 860 s and the I 880 s concepts of racial science and eugenics made notable advances across Europe, which perhaps contributed to the greater proliferation of the ape-like, sub-human figures in cartoons of the Irish Land War in comparison with those of the "great brigandage". Debates on racial differences between Italians did not develop significantly until the I 890 and I900s, when Nicolucci and Sergi began to assert that some Italians were naturally more fit to govern than others, and Lombroso, Ferri, and Niceforo began propagating doctrines of the pre-ordained criminality of some regional people in Italy..$^{90}$ These racial discourses were also politicized in that they were sometimes deployed to discredit the Sicilian-born prime minister, Francesco Crispi. ${ }^{91}$

At the same time, the more advanced stage of racial science in the 1880 s only partly explains the contrast. Cartoons of simianized Irish people predated the Land War and can be found in portrayals of Fenian rebels and agrarian agitators from the 1860 , as in Figures 8 and $9.9^{92}$ Neither were changing concepts of race latecomers to the scientific community in Italy in comparison with England. ${ }^{93}$ During the I 860 s Italian caricaturists were certainly conscious of depicting distinct physical characteristics between African and European people.

The contrast between images of brigands and simianized Irish agitators is better explained by the fact that, in the I860s, many Italian satirical

89. De Nie, The Eternal Paddy, p. 170.

90. Maria Sophia Quine, "Making Italians: Aryanism and Anthropology in Italy during the Risorgimento", in Marius Turda (ed.), Crafting Humans: From Genesis to Eugenics and Beyond (Taipei, 20I3), pp. I27-I 52, I39; Mary Gibson, "Biology or Environment? Race and Southern 'Deviancy' in the Writings of Italian Criminologists, I880-1920", in Schneider, Italy's "Southern Question", pp. 99-1 I5.

91. De Francesco, La Palla al Piede, pp. I45-153.

92. Curtis, Apes and Angels, pp. 29, 37.

93. Il Fischietto, I8 November 1865; Quine, “Making Italians”, p. I 28. 


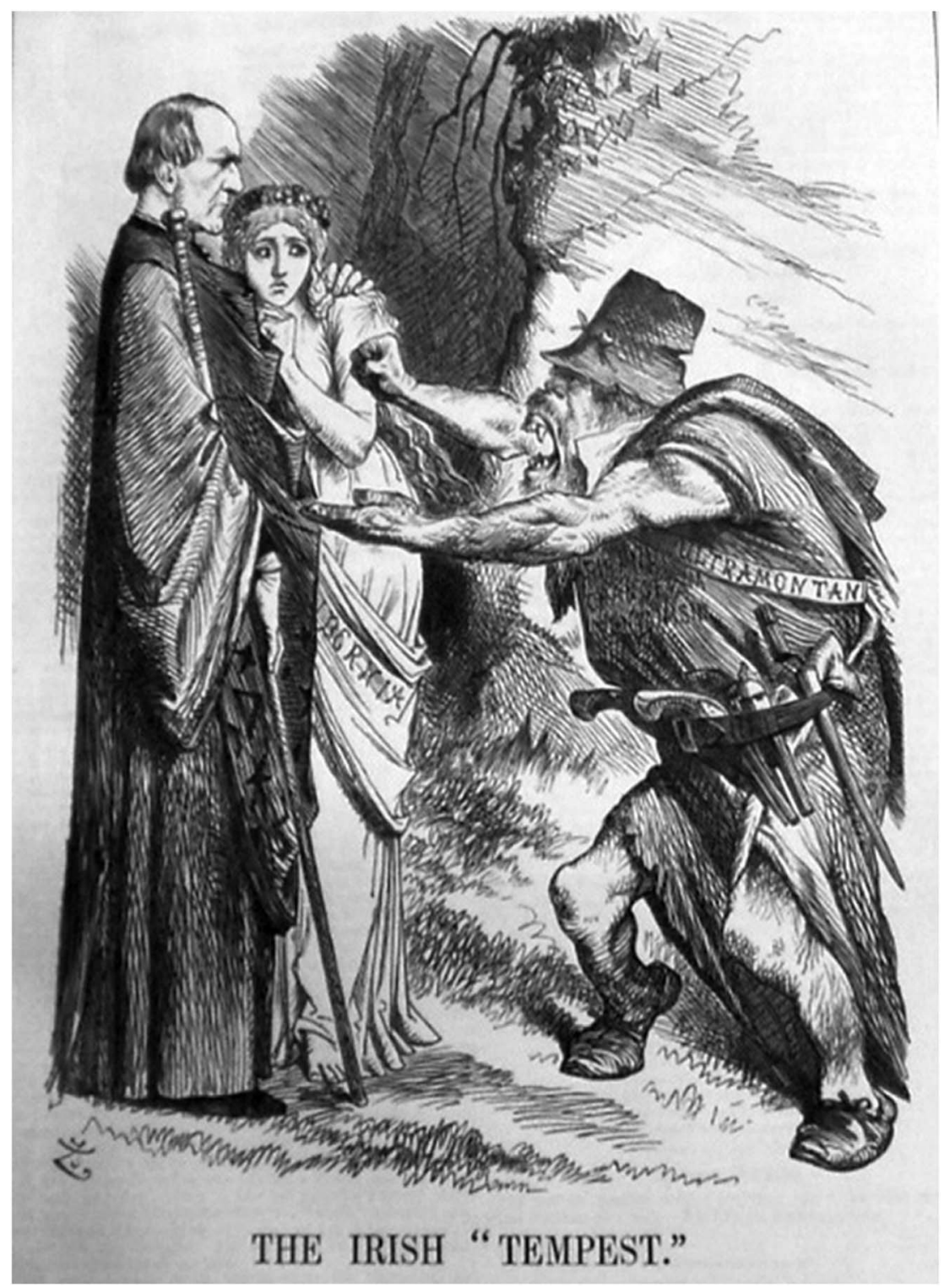

Figure 9. "The Irish 'Tempest”, Punch, I9 March I 870.

National Library of Ireland. Used with permission.

magazines were overtly participating in the political process of making Italy. The Italian army was fighting brigandage with the aim of creating and maintaining a unit, one nation of Italians, and in this context Il Fischietto, Il Lampione, or L'Arlecchino did not exaggerate ethnic 
difference to the same extent as their London counterparts. To be sure, the satirical magazines of the r860s associated southern Italians with criminality and servility, and prefigured the emergence at the end of the century of Lombroso's and Niceforo's internal ethnic hierarchies and pseudo-science of southerners' inferiority. Yet, in the I860s, developing concepts of ethnic difference were shaped by Risorgimento politics. Scientific writing in Italy, Maria Sophia Quine has argued, was an outgrowth of patriotism, a "means to construct a positive national identity" that emphasized the unity of Italians of all regions in a culturally diverse, yet all-inclusive, national community. ${ }^{94}$ On the other hand, cartoons of Irish agitators suggest that concepts of ethnic hierarchies and difference were more developed and politicized in the United Kingdom. Most English, Irish, Scottish, and Welsh people considered themselves to be from culturally distinct regions and perceptions of different regional characteristics, particularly between Britain and Ireland, contributed to the more exaggerated stereotypes and dehumanizing images of Irish people found in the London-based satirical magazines.

In comparison to relations between the mezzogiorno and the Italian government, Ireland's relationship with London was more explicitly colonial, yet cartoons in both cases reveal aspects of internal colonialism, an unequal relationship where people from one region have a subordinate status in a larger state dominated by another. A number of scholars have drawn attention to comparisons that northern officials made between the mezzogiorno and non-European cultures in the years that immediately followed unification. The asymmetrical confrontation and brutal violence of the brigandage wars also brings to mind parallels with the later wars of imperial expansion fought by European powers. Historian Angelo del Boca has cogently described the "great brigandage" as Italy's first colonial conflict, when soldiers and officials' disdain for their adversaries and the use of gruesome force anticipated later incursions into Africa. Another study has argued that the "relationship between north and south was reminiscent of the relationship between European colonizers and African populations". ${ }^{95}$ Yet there was also an internal European context to this relationship that finds parallels and similarities with another peripheral region, Ireland.

Comparison suggests that derogatory images of peasants from both places held local peculiarities, but they also drew from transnational European stereotypes of rural poverty that centred on dependency, laziness, and lawlessness, and which circulated widely due to the rapidly

94. Ibid., pp. I3 1, I46.

95. Angelo Del Boca, Italiani, brava gente? Un mito duro a morire (Vicenza, 2008), p. 57; Aliza

S. Wong, Race and Nation in Liberal Italy, I86I-I9II: Meridionalism, Empire and Diaspora (Basingstoke, 2006), p. 22. 
expanding publishing industry. The appetite for Victorian texts amongst Italian intellectuals, the affinity for Italy in England, the increase of travel writing, and growth of newspaper titles in the mid-nineteenth century all contributed to the busy circulation of these stereotypes between distant places. Colonial attitudes and class prejudices intersected in the perception that unrest and economic underdevelopment in these regions were indicative of a lack of manhood, of the incapacity to overcome dependency on antiquated leaders and structures, and of the reluctance to embrace the political and economic doctrines of liberalism.

Contrived images infused peripheral regions with traits that were the opposite of the virtues of the metropolis, depicting them as uncivilized places, obstacles on the road to modernity. Revolting peasants, whether in Ireland or southern Italy, represented the other as the inversion of the self: the independent, industrious citizen who thrived on liberal capitalism. Through this contrast, cartoons helped to shape and reinforce positive ideas of English and Italian national character. Brigands and Irish agitators were frequently used to personify the peripheral regions they inhabited. They were portrayed as violent, but also dependent, lazy, cowardly, and child-like. Such qualities demonstrated an incapacity for self-government and provided justification for coercive measures, contributing to the moral legitimacy of the Kingdom of Italy and the United Kingdom. Postcolonial studies and scholars of orientalism have emphasized processes of "othering" between the west and east, between the metropole and colony. As has been argued in this article, these assessments should be complemented by the acknowledgment of the internal European context to these relationships based on ingrained class and gendered prejudices.

\author{
TRANSLATED ABSTRACTS \\ FRENCH - GERMAN - SPANISH
}

Niall Whelehan. Paysans en révolte: Italie du Sud, Irlande et images satiriques dans une perspective comparative, I860-I882.

Les paysans en général et les rebelles ruraux en particulier furent impitoyablement ridiculisés dans les images satiriques qui proliférèrent dans les villes européennes à partir de la moitié du dix-neuvième siècle. Mais ces images transmirent plus que l'éternelle hostilité des citadins envers les paysans. Dans cet article, l'auteur procède à une étude comparative de la manière dont les images satiriques des brigands de l'Italie $\mathrm{du}$ Sud et des agitateurs ruraux de l'Irlande contribuèrent à élaborer une version libérale de ce qui était moderne, en identifiant ce qui ne l'était pas: le paysan en révolte qui adoptait un comportement "efféminé", manquait d'autonomie et était sous l'emprise du clergé catholique. Pendant les périodes d'agitation, les distinctions entre les brigands, les rebelles et les populations rurales en général ne furent pas toujours claires dans les images satiriques. La comparaison suggère que les images dénigrantes 
de l'Italie du Sud et de l'Irlande puisèrent dans des particularités locales, mais qu'elles partirent également de stéréotypes internationaux sur la pauvreté rurale, largement diffusés grâce à l'industrie de la publication en pleine expansion. Alors que les débats érudits, inspirés par des perspectives postcoloniales, soulignèrent par le passé des processus d'altérisation entre l'Ouest et l'Est, l'auteur soutient qu'il existe aussi un contexte interne européen à ces relations, fondées sur les préjugés ancrés de classe et de genre, ainsi que sur les perceptions de ce qui constitua le centre et la périphérie.

Traduction: Christine Plard

Niall Whelehan. Aufständische Bauern: Süditalien, Irland, und Karikaturen aus komparatistischer Sicht, I860-I882.

Bauern im Allgemeinen und ländliche Rebellen im Besonderen wurden in den ab Mitte des I9. Jahrhunderts in europäischen Städten verbreiteten satirischen Karikaturen gnadenlos verspottet. In diesen Bildern steckte mehr als nur die jahrhundertealte Feindseligkeit von Stadtbewohnern gegenüber Bauern. Der Aufsatz untersucht mit komparatistischen Methoden, wie Karikaturen süditalienischer Banditen und ländlicher irischer Agitatoren zur Herausbildung einer liberalen Version des Modernen beitrugen, indem sie herausstellten, was nicht in diese Kategorie gehörte: der aufständische Bauer, der sich "unmännlich" verhielt, der Eigenständigkeit entbehrte und dem katholischen Klerus hörig war. In Zeiten der Unruhe wurde in den Karikaturen nicht immer deutlich zwischen Banditen, Rebellen, und der ländlichen Bevölkerung insgesamt unterschieden. Ein Vergleich der Karikaturen legt nahe, dass abwertende Darstellungen süditalienischer und irischer Bauern zwar jeweils lokale Besonderheiten aufwiesen, sich aber zugleich auch transnationaler Stereotype bedienten, denen das rasch expandierende europäische Verlagswesen zu beträchtlicher Verbreitung verhalf. Die von postkolonialen Perspektiven inspirierten wissenschaftlichen Debatten haben bislang stark auf den Prozess des Othering zwischen Westen und Osten, Metropole und Kolonie abgehoben; in diesem Aufsatz wird argumentiert, dass die entsprechenden Beziehungen auch einen europäischen Binnenkontext hatten, der auf tiefsitzenden, klassen- und geschlechtsspezifischen Vorurteilen beruhte, sowie auf Vorstellungen darüber, was als Zentrum und was als Peripherie anzusehen ist.

Übersetzung: Max Henninger

Niall Whelehan. Rebelando campesinos: caricaturas sobre Italia meridional $e$ Irlanda en una perspectiva comparada, I860-I882.

De forma general los campesinos, y de forma más particular los rebeldes en el ámbito rural, fueron ridiculizados de forma despiadada en las caricaturas satíricas que proliferaron en las ciudades europeas desde mediados del siglo XIX. En este tipo de imágenes podemos encontrar algo más que la vieja hostilidad que los habitantes de las ciudades tenían sobre los campesinos y este artículo explora desde la perspectiva comparada como las caricaturas hechas de los bandoleros de Italia 
del Sur y de los agitadores rurales irlandeses contribuyeron a dar forma a una versión liberal de lo que era moderno identificando aquello que no lo era: los campesinos rebeldes con comportamientos "poco viriles", carentes de independencia y sometidos al clero católico. Durante los periodos de agitación, las distinciones existentes entre bandoleros, rebeldes y la población rural en general no siempre quedaban claramente delimitadas en estas caricaturas. La comparación sugiere que las imágenes despectivas del campesinado de la Italia meridional e Irlanda conservan ciertas peculiaridades, pero también permiten trazar una serie de estereotipos transnacionales de la pobreza rural que circularon profusamente debido a la rápida expansión de la industria editorial en Europa. Mientras los debates académicos inspirados en las perspectivas post-coloniales han enfatizado previamente los procesos de alteración (othering) entre el Este y el Oeste, entre la metrópoli y la colonia, se plantea en este texto que también se puede encontrar un contexto europeo interno de este tipo de relaciones basado en la inculcación de una serie de prejuicios de género y de clase, y en percepciones de lo que constituye el centro y la periferia.

Traducción: Vicent Sanz Rozalén 